OAK RIDGE

ORNL/TM-2013/369

NATIONAL LABORATORY

MANAGED BY UT-BATTELLE

FOR THE DEPARTMENT OF ENERGY

\title{
Modeling the Demand for E85 in the United States ${ }^{1}$
}

\section{September 2013}

\author{
Prepared by \\ Changzheng Liu \\ Research Staff \\ David L. Greene \\ Corporate Fellow
}

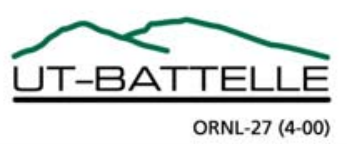

${ }^{1}$ The research described in this report was supported by the Energy Information Administration, U.S. Department of Energy. The views expressed in the report are those of the authors and do not necessarily reflect those of the Energy Information Administration or the Department of Energy. 


\section{DOCUMENT AVAILABILITY}

Reports produced after January 1, 1996, are generally available free via the U.S. Department of Energy (DOE) Information Bridge.

Web site http://www.osti.gov/bridge

Reports produced before January 1, 1996, may be purchased by members of the public from the following source.

National Technical Information Service

5285 Port Royal Road

Springfield, VA 22161

Telephone 703-605-6000 (1-800-553-6847)

TDD 703-487-4639

Fax 703-605-6900

E-mail info@ntis.gov

Web site http://www.ntis.gov/support/ordernowabout.htm

Reports are available to DOE employees, DOE contractors, Energy Technology Data Exchange (ETDE) representatives, and International Nuclear Information System (INIS) representatives from the following source.

Office of Scientific and Technical Information

P.O. Box 62

Oak Ridge, TN 37831

Telephone 865-576-8401

Fax 865-576-5728

E-mail reports@osti.gov

Web site http://www.osti.gov/contact.html

This report was prepared as an account of work sponsored by an agency of the United States Government. Neither the United States Government nor any agency thereof, nor any of their employees, makes any warranty, express or implied, or assumes any legal liability or responsibility for the accuracy, completeness, or usefulness of any information, apparatus, product, or process disclosed, or represents that its use would not infringe privately owned rights. Reference herein to any specific commercial product, process, or service by trade name, trademark, manufacturer, or otherwise, does not necessarily constitute or imply its endorsement, recommendation, or favoring by the United States Government or any agency thereof. The views and opinions of authors expressed herein do not necessarily state or reflect those of the United States Government or any agency thereof. 
Energy and Transportation Science Division

MODELING THE DEMAND FOR E85 IN THE UNITED STATES

\author{
Changzheng Liu \\ David L. Greene
}

Date Published: September 2013

Prepared by

OAK RIDGE NATIONAL LABORATORY

Oak Ridge, Tennessee 37831-6283

managed by

UT-BATTELLE, LLC

for the

U.S. DEPARTMENT OF ENERGY

under contract DE-AC05-00OR22725 



\section{CONTENTS}

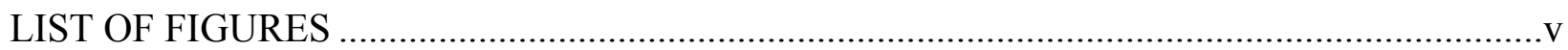

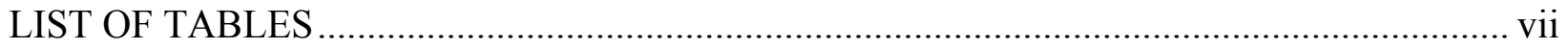

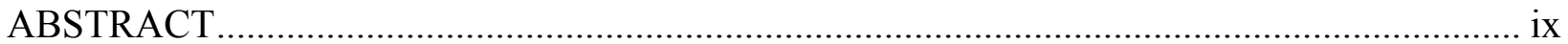

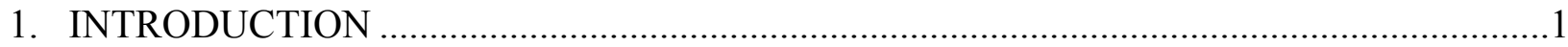

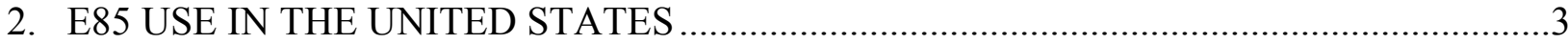

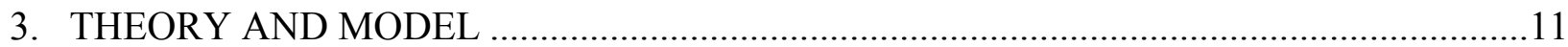

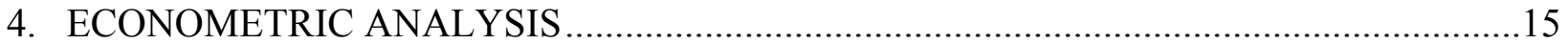

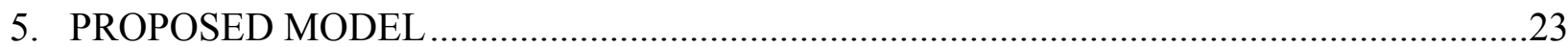

6. CONCLUSIONS

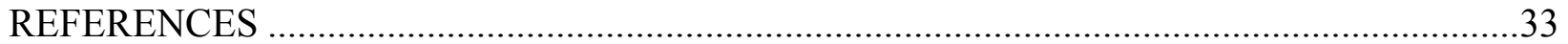

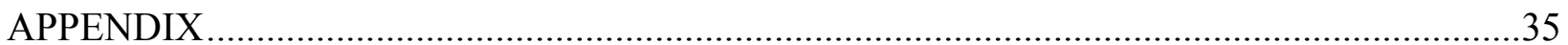





\section{LIST OF FIGURES}

Figure

Page

1 EIA Estimates of E85 Use in the United States: "Estimated Consumption of Vehicle Fuels in Gasoline Equivalent Gallons by Fuel Type, 2007-2011 3

2 EIA Alternative Fuel Vehicle Data: Fuel Use Data by Region ......................................4

3 Reported and EIA Fleet Survey E85 Use for Three States ..............................................5

4 Monthly Sales of Gasoline and E85 in Minnesota.....................................................5

5 Monthly Prices of E10 and E85: 2012 Dollars per E10 Equivalent Energy....................6

6 E85 Share of FFV Energy Use and Station Availability in Minnesota ...........................7

$7 \quad$ E85 and Gasoline Prices in Minnesota ...................................................................... 16

8 Cost of Limited Fuel Availability in Minnesota Implied by NLS and 2SLS

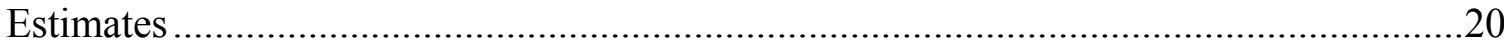

9 Regression Residuals in Original Minnesota Model ................................................20

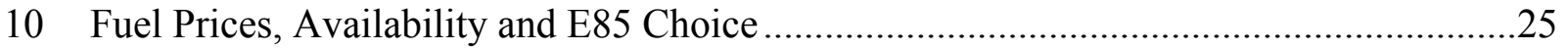

11 FFV Stocks and E85 Use: AEO 2013 Inputs.........................................................26

12 Distribution of U.S. Gasoline Stations by Region: Census Counts vs. Gasoline

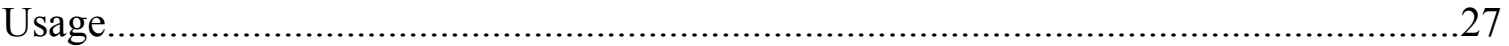

13 Predicted and EIA E85 Use for Nine Census Regions in 2010 ...................................28

14 Calibrated Model: Predicted vs. Survey Estimate of E85 Use in 2010 .........................29

15 Regional E85 Model Projections Using Data from the AEO 2013 Reference Case .........30 



\section{LIST OF TABLES}

Table

1 Choice Equation Estimation Results for Minnesota .............................................18

2 Short-run and Long-run Own Price Elasticity of E85 Choice .......................................19

3 Coefficients of the Regional E85 Choice Model .......................................................29 



\begin{abstract}
How demand for E85 might evolve in the future in response to changing economics and policies is an important subject to include in the National Energy Modeling System (NEMS). This report summarizes a study to develop an E85 choice model for NEMS. Using the most recent data from the states of Minnesota, North Dakota, and Iowa, this study estimates a logit model that represents E85 choice as a function of prices of E10 and E85, as well as fuel availability of E85 relative to gasoline. Using more recent data than previous studies allows a better estimation of non-fleet demand and indicates that the price elasticity of E85 choice appears to be higher than previously estimated. Based on the results of the econometric analysis, a model for projecting E85 demand at the regional level is specified. In testing, the model produced plausible predictions of US E85 demand to 2040.
\end{abstract}





\section{INTRODUCTION}

The Renewable Fuels Standard (RFS) II requires 36 billion gallons of renewable fuels be sold in the United States by 2022 (NRC, 2011). At present, although the U.S. Environmental Protection Agency (EPA) has extended the limit for blending ethanol with gasoline from $10 \%$ to $15 \%$, the higher limit applies only to vehicles manufactured after 2001 (EPA, 2013), and automobile manufacturers have raised concerns about invalidating the warrantees of even late model vehicles by use of E15. Another possible route to compliance with the RFS II is much greater use of E85 by flex-fuel vehicles (FFVs). There are approximately 11 million FFVs in use in the United States, capable of using any mixture of E85 and E10 (Schill, 2012). Since essentially all gasoline sold in the United States is now E10, the terms E10 and gasoline will be used interchangeably in this report.

Currently, E85 sales are very limited, largely due to the lack of refueling infrastructure but also to the relatively small number of FFVs and the lack of a decided price advantage for E85 on an energy equivalent basis. How demand for E85 might evolve in the future in response to changing economics and policies is an important feature to include in the National Energy Modeling System (NEMS).

This report summarizes a study to develop an E85 choice model for NEMS. E85 use and related data are described in the following section. Comprehensive data on national E85 sales does not exist; the best national data available come from a survey of fleet vehicles subject to alternative fuel use requirements (EIA, 2013a). The best available data on E85 use that includes both relative high market shares, a majority of sales to non-fleet customers, and relatively high E85 availability come from the state of Minnesota. Section 3 presents a theory of E85 choice and derives the equations of a national model of E85 choice. Section 4 describes an econometric analysis of data, from Minnesota, North Dakota and Iowa, and the results of the analysis. Using more recent data than previous studies allows a better estimation of non-fleet demand and indicates that the price elasticity of E85 choice appears to be higher than previously estimated. Recommendations for modeling E85 in NEMS are presented in Section 5, which also presents illustrative results from national and regional test versions of the model. 


\section{E85 USE IN THE UNITED STATES}

There is no comprehensive source of data on E85 use in the United States. This not only makes it difficult to infer coefficients for a model of E85 choice but severely limits the possibility of testing the model against data not used in its estimation. The best available data on E85 use is the Energy Information Administration's (EIA's) “Alternative Fuel Vehicle Data: User and Fuel Data," which is based on a survey of fleets subject to alternative fuels regulations. While the survey covers all states, it apparently excludes a substantial amount of E85 use by private motorists, at least in some states (EIA, 2013a). The data available through 2011 show substantial growth in E85 use but only 137 million gallons consumed in 2011 (Figure 1).

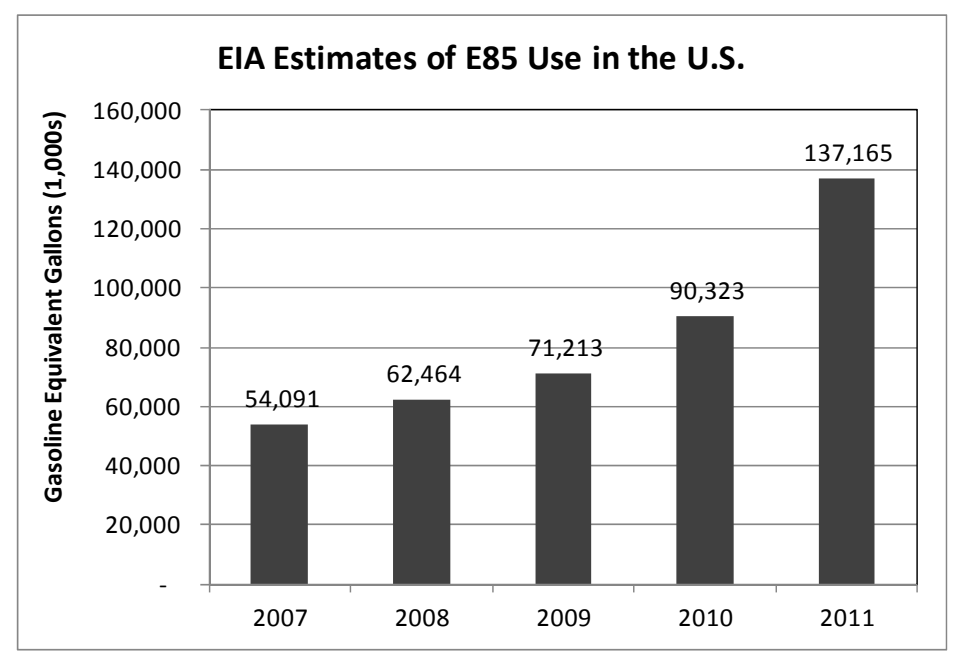

Figure 1. EIA Estimates of E85 Use in the United States: "Estimated Consumption of Vehicle Fuels in Gasoline Equivalent Gallons by Fuel Type, 2007-2011,” http://www.eia.gov/renewable/afv/ .

The EIA survey data can be downloaded and aggregated to the state or regional level. The regional data also show increases in all regions, with the South Atlantic having the highest levels of E85 use (Figure 2). 


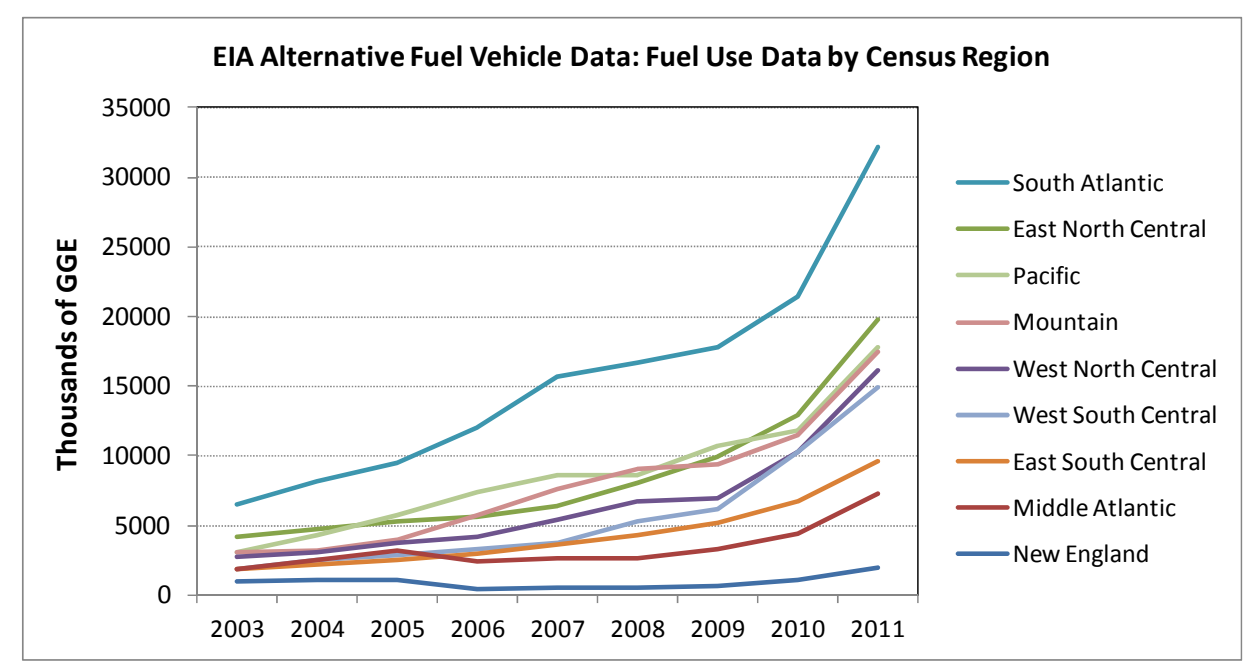

Figure 2. EIA Alternative Fuel Vehicle Data: Fuel Use Data by Region.

The EIA survey, however, applies only to fleets subject to alternative fuels regulations. Figure 2 compares data collected by the states of Minnesota, Iowa and North Dakota on E85 sales to all types of customers to the EIA estimates for those states. In recent years, the state-reported estimates substantially exceed the EIA survey estimates, although there are years in which the reverse is true for Iowa and North Dakota. Minnesota and Iowa are among the states that have actively promoted E85 use and E85 availability. How other states' E85 use differs from the EIA survey data is not known, although it is likely that the EIA estimates are a reasonable approximation of total E85 use in states where the E85 station network is extremely sparse and government programs have not vigorously promoted E85 use by privately-owned vehicles. In those states, and even in Minnesota until about 2004, the majority of E85 use appears to have been by fleets subject to alternative fuels regulations. After 2004, especially in Minnesota, the mixture of fleet use and private motorist use shifts decidedly in favor of private motorists. This could well have implications for the sensitivity of market share to both prices and fuel availability. It seems reasonable to hypothesize that use of E85 by fleets required to use alternative fuels might be less sensitive to price or availability than private vehicle use.

The Minnesota E85 data are the most detailed and complete available. E85 use in Minnesota increased sharply in 2005 and 2006, almost entirely due to increased sales to private motorists (Figures 3 and 4). At the same time, gasoline sales were gradually declining. E85 sales dropped by about 500,000 gallons per year between 2008 and 2009 and remained at approximately that level until 2012. Both gasoline and E85 sales display pronounced seasonality. 


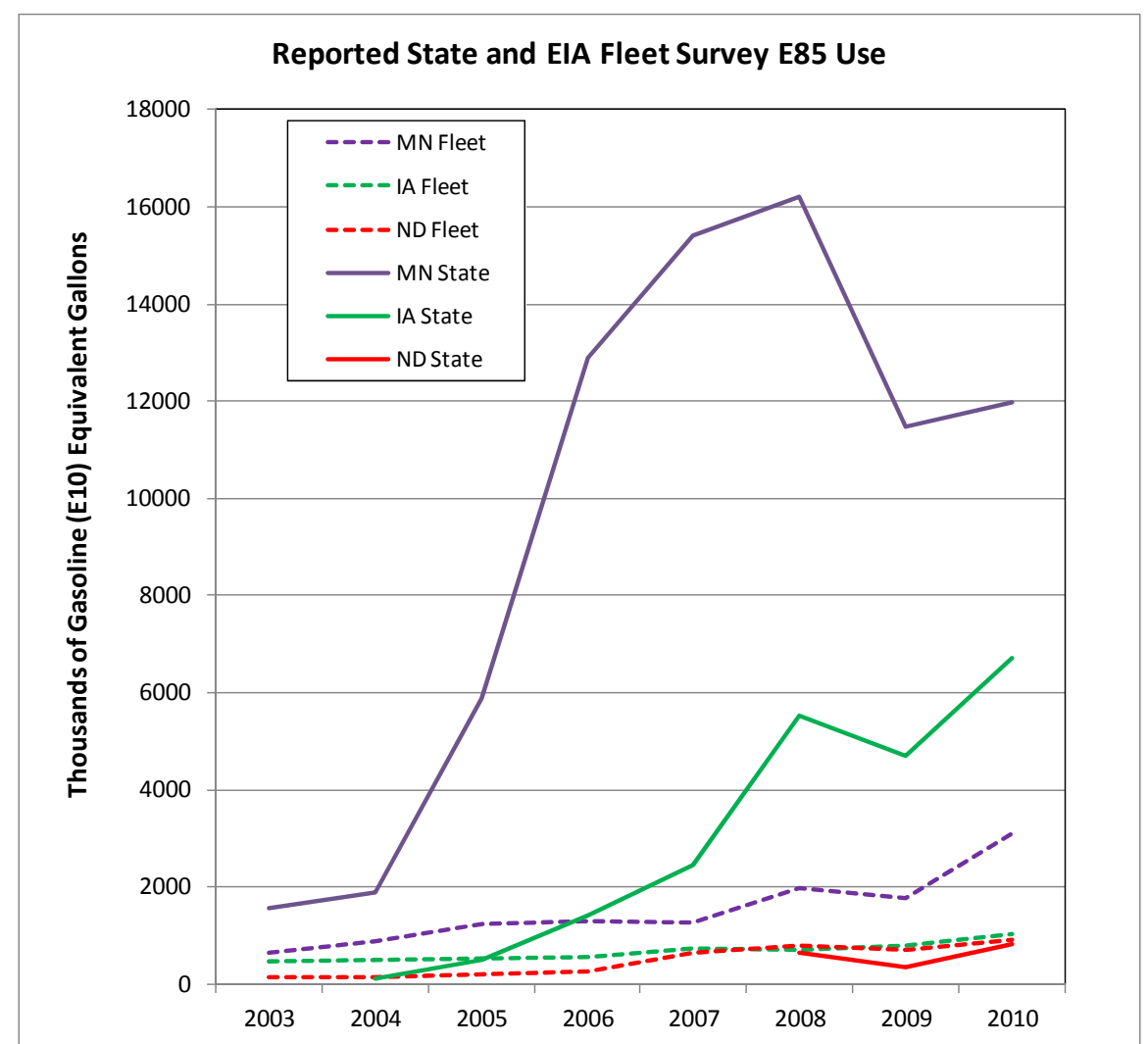

Figure 3. Reported and EIA Fleet Survey E85 Use for Three States.

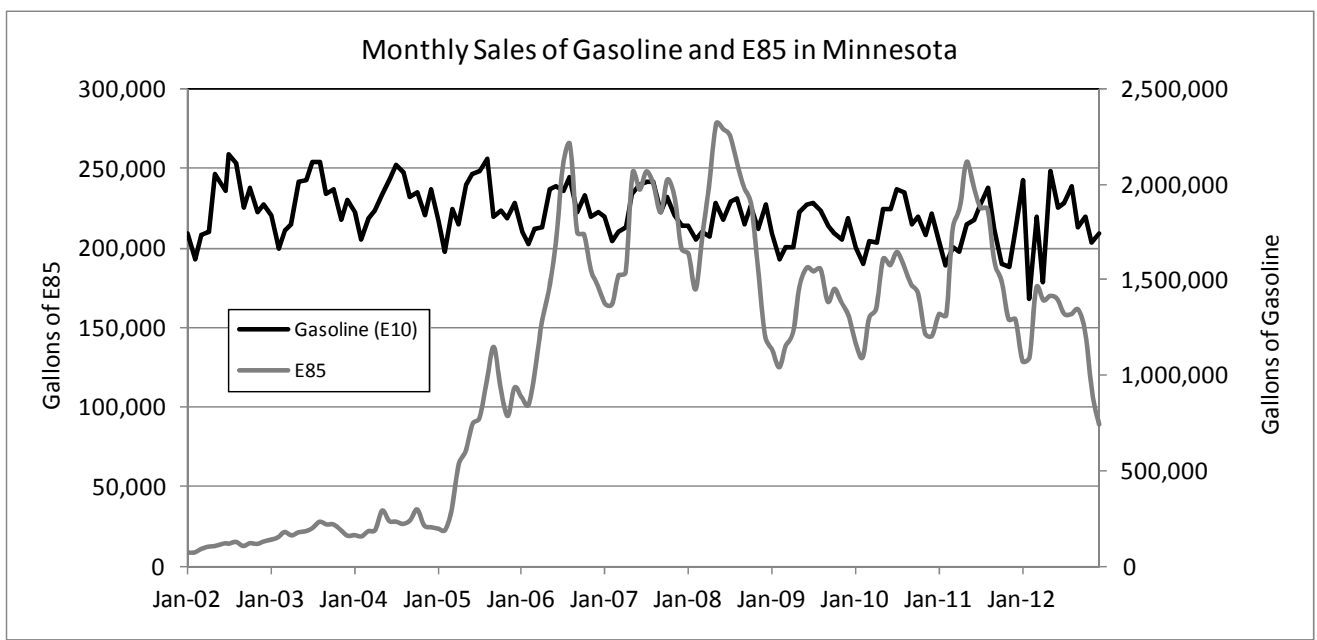

Figure 4. Monthly Sales of Gasoline and E85 in Minnesota.

Although the per gallon price of E85 has been consistently below that of E10, E85 has been consistently more expensive than E10 on the basis of the energy content of the two fuels (Figure 5). The price difference has varied from a few cents per gallon of E10 equivalent to more than $\$ 0.50$. The energy content of E85 relative to E10 varies over both time and place. 
Although E85 is nominally comprised of $85 \%$ ethanol and $15 \%$ gasoline, in reality the blending ratio varies considerably over time, from as little as $51 \%$ ethanol to as much as $83 \%$ ethanol, in part to adjust for the lower volatility of ethanol relative to gasoline, especially in cold weather. Fuel ethanol is distributed in denatured form, containing from $2 \%$ to $5 \%$ hydrocarbon (typically gasoline) to discourage human consumption and so even a blend of exactly $15 \%$ gasoline and $85 \%$ denatured ethanol would be no more than $83 \%$ ethanol. On the EPA's fuel economy tests, a blend of $81 \%$ ethanol and 19\% indolene is used. On the EPA's tests, FFVs tested on E85 get $27 \%$ fewer miles per gallon than when the same vehicles are tested on pure gasoline (Thomas, Huff, and West, 2012). This is about 2-3\% better than the relative energy contents of the fuels, indicating that burning E85 in an FFV gives a small energy efficiency benefit. Given the variability of E85 blends, it is assumed here that E85 provides $77 \%$ of the energy services of E10.

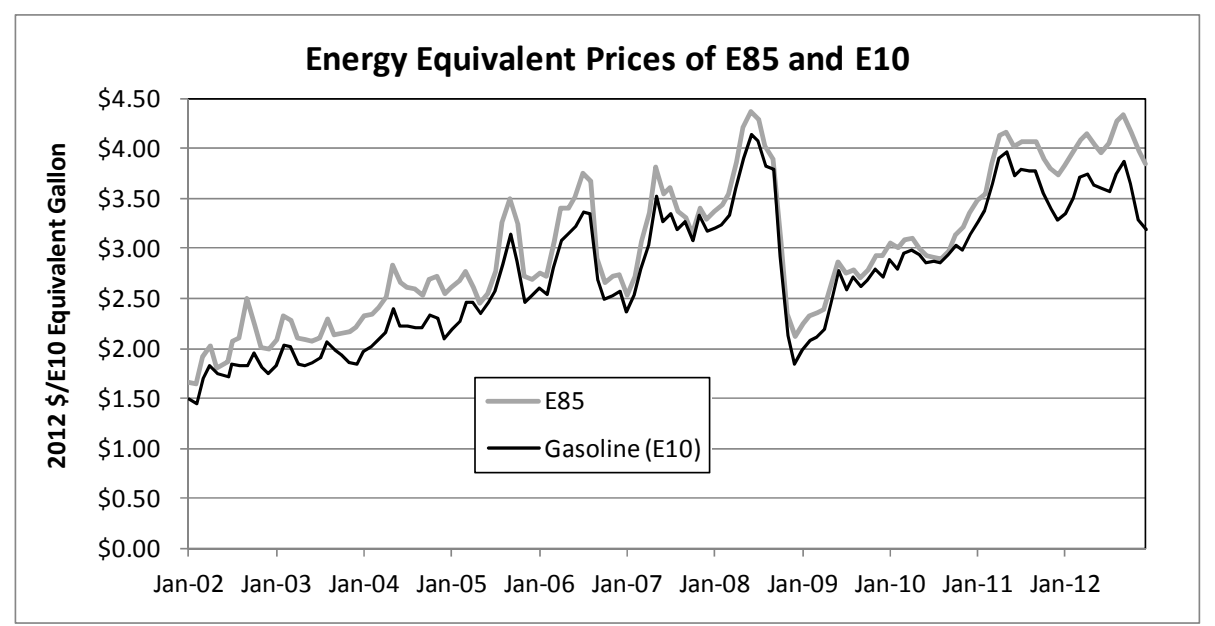

Figure 5. Monthly Prices of E10 and E85: 2012 Dollars per E10 Equivalent Energy.

The share of estimated energy services used by FFVs in Minnesota that was supplied by E85 increased from about 2\% in January 2002 to a high of 25\% in August 2006 (Figure 6). The E85 share fell to $10 \%$ in December 2008 and dropped below 5\% again in November and December of 2012. The ratio of refueling stations offering E85 to the total number of gasoline refueling stations increased from 2\% in January 2002 to $10 \%$ in July of 2008 and has remained at about 10\% since. The number of FFVs registered in Minnesota has grown relatively steadily from just over 50 thousand in early 2002 to over 350 thousand by the end of 2012 . 


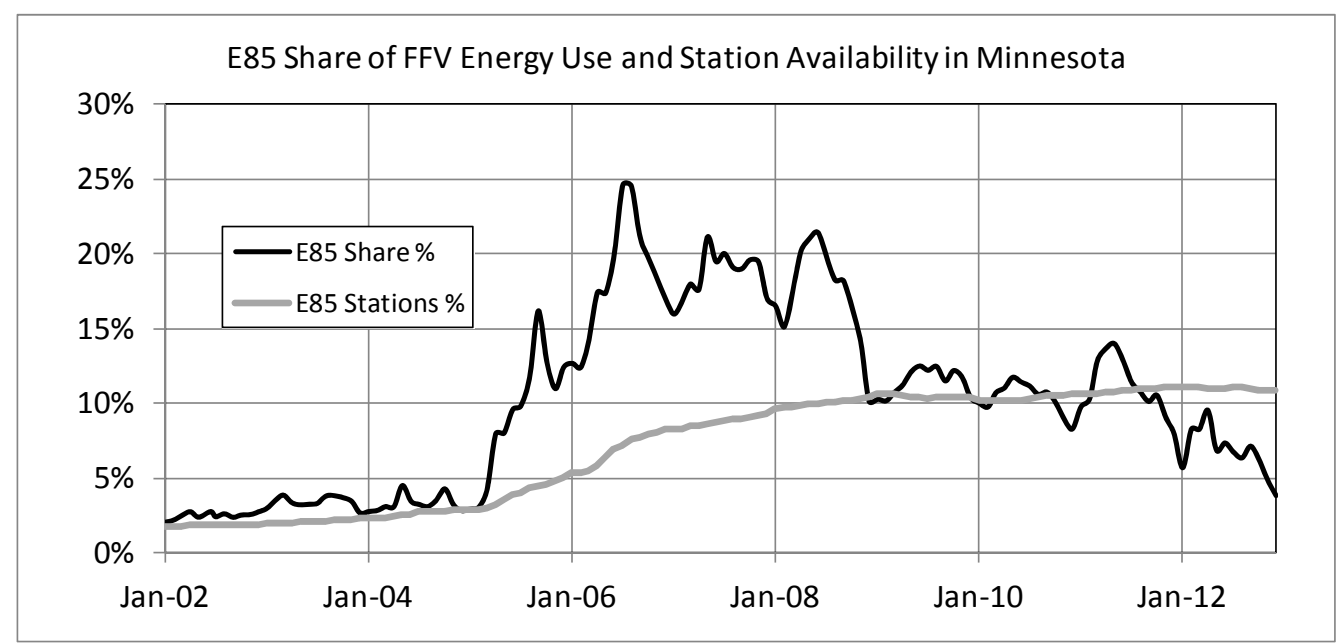

Figure 6. E85 Share of FFV Energy Use and Station Availability in Minnesota.

Four previous studies have estimated the effects of fuel prices on the demand for E85. Three used data from the state of Minnesota, the fourth used data from six cities in Brazil. Anderson (2006) estimated an aggregate demand model of E85 sales at retail outlets offering both E85 and gasoline in Minnesota. Since the observational unit was sales shares at individual retail outlets offering E85, it was not possible to estimate the cost of limited fuel availability. Using two-stage least squares (2SLS) estimation to account for simultaneity of E85 price and quantity, Anderson estimated a wide range of price elasticities from -3 to -20 (the preferred model had an elasticity of -13), depending on the functional form chosen and the price level. Because Anderson's data covered the period October 1997 to June 2006, it reflects a mixture of mostly earlier periods dominated by fleet use of E85 plus two final years in which use by private vehicles was more important (Figure 3).

Greene, Zhou and Wilson (2009) estimated an E85 choice model using a decade of monthly E85 sales data from Minnesota. The dependent variable was defined as the E85 share of total energy services used by FFVs in Minnesota. The share was calculated by dividing reported E85 sales converted to gasoline gallons energy equivalent by total FFV energy services required, estimated by multiplying the number of FFVs on the road in Minnesota in month $t$ by the average energy use per light-duty vehicle (gasoline plus FFV) in Minnesota in that month. This method assumes that FFVs and non-FFVs have the same demand for energy services, on average. A logit model was assumed, which leads to the following equation for the share of $\mathrm{E} 85, \mathrm{~s}_{\mathrm{E}}$, in terms of the difference of utility indexes of gasoline, $\mathrm{U}_{\mathrm{G}}$, and $\mathrm{E} 85, \mathrm{U}_{\mathrm{E}}$.

$$
\begin{aligned}
\ln \left(\frac{1}{s_{E t}}-1\right)= & U_{G t}-U_{E t} \\
& =\left(a_{0 G}-a_{0 E}+a_{2} \exp \left(a_{3}\right)\right)+a_{1 G} P_{G t}-a_{1 E} P_{E t}-a_{2} \exp \left(a_{3} f_{t}\right)+\varepsilon_{t}
\end{aligned}
$$


$\mathrm{P}_{\mathrm{G}}$ and $\mathrm{P}_{\mathrm{E}}$ are the prices of gasoline and $\mathrm{E} 85$, respectively, and $\varepsilon$ is a random error. The nonlinear term, $a_{2} \exp \left(a_{3} f_{t}\right)$, represents the cost of limited fuel availability as a function of, $f$, the ratio of outlets offering E85 to total outlets offering gasoline (for E10, $\mathrm{f}=1$ by definition). The a's are coefficients to be estimated.

Greene, Zhou and Wilson (2009) found that a model that assumed that consumers gradually learned that the energy content of E85 was less than the energy content of gasoline fit the data better than a model that represented prices as either strictly based on volume or strictly based on energy content. The cost of limited fuel availability was estimated to be $\$ 2$ per gallon at $1 \%$ availability, declining to $\$ 0.33$ per gallon at $10 \%$ availability and $\$ 0.04$ per gallon at $20 \%$ availability. The price elasticity of the E85 market share at a 5\% market share and a price of $\$ 3.25$ per gallon was estimated to be -2.7 . The coefficient $\mathrm{a}_{3}$, which determines the rate of decline in the cost of limited fuel availability, was estimated to be -20 .

Anderson (2012) again used Minnesota data on sales at stations offering E85 to estimate a model of E85 demand. The data came from a survey of individual retail stations in which stations receiving state funding were required to respond while others could respond voluntarily. The data start in October 1997 and data through November 2006 were used in the statistical analysis. Anderson reports that the number of E85 stations in Minnesota increased from 10 to nearly 250 over this time period and that his sample represents about $65 \%$ of those stations. The model he estimated represented the log of demand for E85 at station $\mathrm{i}$ in month $\mathrm{t}$ as a function of the logarithm of the price of E85, $\mathrm{P}_{\mathrm{Et}}$, the price difference between $\mathrm{E} 85$ and gasoline $(\mathrm{E} 10), \mathrm{P}_{\mathrm{Gt}}$, variables representing county and station attributes, $\mathbf{X}_{\mathrm{it}}$, and fixed effects for stations, $\delta_{\mathrm{i}}$, and months, $v_{\mathrm{t}}$, a time trend for each station, $\omega_{\mathrm{i}} \mathrm{t}$, and a random error, $\varepsilon_{\mathrm{it}}$.

$$
\ln \left(q_{i t}\right)=\alpha \ln \left(P_{E t}\right)+\beta\left(P_{E i t}-P_{G i t}\right)+\gamma^{\prime} X_{i t}+\delta_{i}+v_{t}+\omega_{i} t+\varepsilon_{i t}
$$

The inclusion of the term $\alpha \ln \left(\mathrm{P}_{\mathrm{Et}}\right)$ is intended to measure the short-run price elasticity of overall fuel demand and was set $=0$ in many of the model variations estimated. Anderson focuses on the response to the $\mathrm{E} 85$ price premium: $\mathrm{P}_{\mathrm{E}}-\mathrm{P}_{\mathrm{G}}$. The equation was estimated by means of ordinary least squares (OLS) and two-stage least squares (2SLS), which would be more appropriate if the price of E85 were endogenous. He notes that in his preferred models, a $\$ 0.10$ increase in the price premium results in a $12 \%$ to $16 \%$ decrease in the quantity of ethanol demanded.

The overall elasticity of demand with respect to the price of E85 in Anderson's model is a function of the price of E85: $\alpha+\beta \mathrm{P}_{\mathrm{E}}$. The preferred models assume $\alpha=0$, so that the price elasticity is $\beta \mathrm{P}_{\mathrm{E}}$. In the OLS model $\beta=-1.32$ and the mean E85 price in the Minnesota data was 2.37 (2006 \$), for a mean price elasticity of -3.1 . In the 2 SLS model the $\beta=-1.62$ for a mean elasticity of -3.8 . A price of $\$ 3.25$ per gallon would imply a range of elasticities of -4.3 to -5.3 . 
Based on discussions with E85 retailers, Anderson (2012) concluded that the degree to which E85 prices were a function of E85 demand was very limited. Noting that the price of E85 was generally lower than gasoline on a volume basis but higher than gasoline on the basis of energy content, he concluded that the E85 energy price premium was largely determined by the prices of gasoline and ethanol.

"Average premiums generally increase when wholesale cost for $\mathrm{E} 85$ rise relative to gasoline, and premiums shrink when costs fall. The economic causality is decidedly one-sided: events specific to the tiny E85 market have zero bearing on prices for crude oil, gasoline, or even ethanol, whose primary role is as a gasoline additive." (Anderson, 2012, p. 158)

While this reasoning is sound, in the statistical analysis we find inconclusive evidence for endogeneity of the price of E85 and a somewhat higher price response using 2SLS estimation. Fortunately, for practical purposes the differences between the 2SLS estimates and the OLS estimates are small.

Anderson (2012) also compared his preferred model to a model using first differences of the data. The price responses in the first differences formulation were $20 \%$ to $30 \%$ smaller. Anderson hypothesized that this might be due to a delay in the response of demand. Using a lagged adjustment model, below, we too find that full adjustment to price changes takes more than a single month.

Anderson's (2012) model produces some anomalous results, however. The estimates implied that a $1 \%$ increase in the number of FFVs would lead to less than a $0.1 \%$ increase in E85 sales. In part, he attributed this result to the fact that he estimated FFVs on the road from FFV registrations for a single year: 2007. It may also be due to the fact that much of the E85 use in his sample was by regulated fleets rather than the general public.

Salvo and Huse (2013) estimated a disaggregate probit choice model from revealed preference survey data collected in six Brazilian cities in 2009-2010, a period in which ethanol prices per gallon varied from less than $70 \%$ to more than $90 \%$ of the price of gasoline. The availability of E85 in Brazil is similar to that of gasoline. Motorists were interviewed at the refueling station after they had made their choice of fuel. The analysis revealed substantial heterogeneity in consumers' preferences with about $20 \%$ of motorists choosing E85 when it was priced $20 \%$ higher than gasoline on an energy equivalent basis and $20 \%$ choosing gasoline when it was priced $20 \%$ above E85 on an energy equivalent basis. Wealthier, older motorists and those who drove long distances tended to prefer gasoline, while those living in sugar-growing areas and showing greater concern for the environment tended to prefer E85. Although the authors do not report price elasticities, a very rough calculation of the aggregate market price elasticity using the arc elasticity formula on the wide range of market shares in the statement above ( $20 \%$ to $80 \%)$ 
indicates a price elasticity of about -3 in the vicinity of a $50 \%$ market share $((60 \% / 50 \%) /(-40 \% / 100 \%))$. Figure 6 in the paper indicates that for a median Brazilian consumer, a $10 \%$ reduction in the price of E85 is associated with approximately a doubling of choice probability (market share) for E85 market shares in the range of $10 \%$ to $20 \%$. This is a greater price elasticity (about -10) than that found by Greene, Zhou and Wilson (2009) or Anderson (2012). On the other hand, a price elasticity of approximately -10 is less price sensitive than what earlier studies in the United States found for the choice among gasoline grades (Greene, 1989: -15 to -20) and full versus self-service dispensing (Phillips and Schutte, 1988: -35 and -40). However, the curve from which the -10 elasticity was estimated should be more price elastic than the market as a whole since it represents a median motorist and so does not take account of the heterogeneity of preferences across consumers. 


\section{THEORY AND MODEL}

Motor fuels provide energy services to consumers by supplying the energy to produce vehicle travel economically and with a certain degree of performance and safety. It is appropriate, therefore, to model the share of energy services for which consumers will choose E85 rather than the volumetric share of E85. The choice of E85 by motorists depends on three main factors:

1. Ownership of an FFV capable of using E85,

2. The existence of $E 85$ refueling infrastructure, and

3. The prices of E85 and E10 (conventional gasoline), $\mathrm{P}_{\mathrm{E}}, \mathrm{P}_{\mathrm{G}}$.

Preferences for refueling frequency, oil dependence and environmental issues may also affect consumers' fuel choices. Let $\gamma$ be the energy services provided by a gallon of E85 relative to a gallon of E10 (gasoline). Since the energy efficiency of FFVs using E85 is virtually identical to their energy efficiency when using E10, $\gamma$ is calculated as the lower heating value (LHV) energy content of E85 relative to gasoline (Thomas, Huff and West, 2012). The share of energy services a typical consumer will demand as E85 in year $t$ is defined in equation 3, where $\mathrm{q}_{\mathrm{Et}}$ is the gallons of E85 and $\mathrm{q}_{\mathrm{Gt}}$ the gallons of gasoline used by a single FFV in year $\mathrm{t}$.

$$
s_{E t}=\frac{\gamma q_{E t}}{q_{G t}+\gamma q_{E t}}
$$

The utility of E85 to a representative consumer is assumed to be a linear function of its price, $\mathrm{P}_{\mathrm{Et}}$, its availability measured as the fraction of total gasoline outlets offering E85 $\left(\mathrm{f}_{\mathrm{t}}\right)$ other factors, $\mathrm{X}_{\mathrm{t}}$, and a random variable, $\varepsilon_{\mathrm{Et}}$, which reflects differences in utility indices across consumers not represented by the other variables (equation 4 ).

$$
U_{E t}=A_{0 E}+A_{1 E} P_{E t}+A_{2 E} \exp \left(A_{3 E} f_{E t}\right)+A_{4 E} X_{E t}+\varepsilon_{E t}
$$

The parameters $A_{i t}$ are assumed to be constants translating one unit of each variable into a number of utils (utility index). There is a similar equation for the utility of gasoline, $\mathrm{U}_{\mathrm{Gt}}$, except that its availability is $f=1$, by definition. Although all the coefficients in equation 4 are specific to E85, it is reasonable to expect that the price and fuel availability coefficients might be the same for both fuels.

If the random variable in equation 4 has a type I extreme value distribution, then the probability of E85 choice (equivalent to its market share) is a logit function of the E85 and gasoline utility indexes. 


$$
s_{E t}=\frac{\exp \left(U_{E t}\right)}{\exp \left(U_{E t}\right)+\exp \left(U_{G t}\right)}=\frac{1}{1+\exp \left(U_{G t}-U_{E t}\right)}
$$

Taking the logarithm of the ratio $\left(\mathrm{s}_{\mathrm{Et}} / \mathrm{s}_{\mathrm{Gt}}\right)$ produces an equation that is convenient for statistical inference using the aggregate monthly data on E85 sales.

$$
\begin{aligned}
\ln \left(\frac{S_{E t}}{s_{G t}}\right)=U_{E t} & -U_{G t} \\
& =A_{0 E}-A_{0 G}+A_{1}\left(P_{E t}-P_{G t}\right)+A_{2}\left[\exp \left(A_{3} f_{E t}\right)-\exp \left(A_{3}\right)\right]+A_{4}\left(X_{E t}-X_{G t}\right)
\end{aligned}
$$

In equation 6, only the constant terms are assumed to differ between the two utility indexes, an assumption that will be tested for the price coefficients in section IV. In the econometric estimation described in section IV, the lagged dependent variable (i.e. $\ln \left(\frac{s_{E t-1}}{s_{G t-1}}\right)$ ) was added to equation 6, replacing the term $\left(X_{E t}-X_{G t}\right)$, with the intention of reflecting the lagged response of consumers to changes of prices and other attributes. The term $A_{2} \exp \left(A_{3}\right)$ could be explicitly represented or implicitly included in the difference of the constant terms. Only the difference of the two constant terms can be estimated, however, this is inconsequential since multiplying the numerator and denominator of equation 3 by a constant term ( such as $\exp \left(\mathrm{A}_{0 \mathrm{~g}}\right)$ ) will not change the market shares.

The option to choose E85 is available only for FFVs. For the purpose of predicting future E85 use by FFVs, demand for energy services per FFV $\left(\mathrm{Q}=\mathrm{Q}_{\mathrm{E}}+\mathrm{Q}_{\mathrm{G}}\right)$ is defined as the demand for vehicle services (vehicle miles $=V_{F F V}$ ) divided by their fuel economy (miles per gallon of gasoline equivalent $=\mathrm{MPG}_{\mathrm{FFV}}$ ). FFV technology is essentially transparent to the motorist and it should therefore be a reasonable approximation to assume that, for a given vehicle type, demand for FFV vehicle services is the same as demand for non-FFV vehicle services. Furthermore, available evidence indicates that the energy content efficiency (as opposed to volumetric fuel economy) of an FFV is essentially identical whether it is using gasoline or E85. Thomas, Huff, and West (2012) found a 2-3\% energy efficiency advantage for E85. Given these two premises, the total demand for energy services by FFVs can be estimated independently of their choice between $\mathrm{E} 85$ and gasoline. Let $\mathrm{N}_{\mathrm{FFV}, \mathrm{t}}$ be the number of FFVs on the road in year $\mathrm{t}$ (vehicle type is omitted to simplify equation 7).

$$
Q_{F F V t}=\frac{V_{F F V, t}}{M P G_{F F V, t}} N_{F F V, t}
$$


Given the total demand for energy services by FFVs, their demand for E85 in gasoline equivalent gallons is the product of $\mathrm{Q}_{t}$ and $\mathrm{s}_{\mathrm{Et}}$. The volumetric demand for $\mathrm{E} 85$ is given by equation 8 .

$$
Q_{E t}=\frac{s_{E t} Q_{F F V t}}{\gamma}
$$




\section{ECONOMETRIC ANALYSIS}

The econometric estimation of the E85 choice equation requires data on E85 and gasoline prices and quantities sold, numbers of stations offering E85 and the total number of gasoline stations, and numbers of FFVs in operation. Data sources and their references are listed in Appendix Table 1. Via literature and internet search and personal communications, we found three states that report E85 sales:

1. Minnesota has the most comprehensive E85 database, including monthly time series of E85 sales, number of stations offering E85 and E85 prices from 1997 to 2012;

2. North Dakota has monthly E85 sales data available from July 2007 - Dec 2012; and

3. Iowa has monthly E85 sales available for 2004 -2005, but reported only quarterly sales thereafter.

Estimates of the numbers of FFVs and total vehicles in operation as of January 1 from 2002 to 2013 were purchased from RL Polk and Company. The annual estimates of FFVs and total vehicles were linearly interpolated to estimate monthly counts. Similarly, the number of gasoline stations as of June 1 each year was also linearly interpolated to obtain monthly counts. Daily E85 prices for Iowa and North Dakota were obtained from www.e85prices.com and were averaged to estimate monthly prices. The monthly data for Iowa was summed to produce a quarterly time series for 2004 -2012, and monthly prices were averaged to produce quarterly prices. All prices were converted to Dec 2012 dollars using Consumer Price Index (CPI-U).

\section{Learned E85 Prices}

Fully informed rational consumers would be aware of the reduced energy content of E85 and thus interpret its price and base their fuel choices on the energy services E85 can produce rather than on its volume. However, lack of knowledge and experience in the early period of E85 adoption might have led consumers to believe that one gallon of E85 provides the same energy service as one gallon of gasoline. In this paper, we model consumers' valuation of E85 energy services as a process of learning: FFV owners might initially believe that E85 would provide the same energy services as gasoline but would then learn through their own or other people's experience that it would not. We tested a "learned price" variable which remains the same as the volumetric price until time $\mathrm{t}_{0}$ and then converges toward the energy equivalent price on energy basis as a function of cumulative consumption. The learning function was assumed to be exponential: $e^{-\alpha Q_{t}}$, where $\alpha$ is the learning rate and $\mathrm{Q}_{\mathrm{t}}$ is cumulative consumption of $\mathrm{E} 85$ since time $\mathrm{t}_{0}$ in millions of gallons. The learned E85 price $P_{E}$ is $e^{-\alpha Q_{t}} * P_{E_{-} v o l}+\left(1-e^{-\alpha Q_{t}}\right) * P_{E_{-} g g e}$,

where $P_{E_{-} v o l}$ is volumetric E85 price and $P_{E_{-} g g e}$ is energy equivalent E85 price. The learned price is used in equation 6 for econometric estimation. We programmed a script to enumerate 
possible values of $t_{0}$ and $\alpha^{1}$ to find the combination that maximizes R-squared of the non-linear least squares (NLS) regression model. Figure 7 shows volumetric and energy equivalent E85 and gasoline prices, as well as learned E85 prices in Minnesota. Assuming that learning started from August of 2006 with a learning rate of 0.025 produced the best fit to the data.

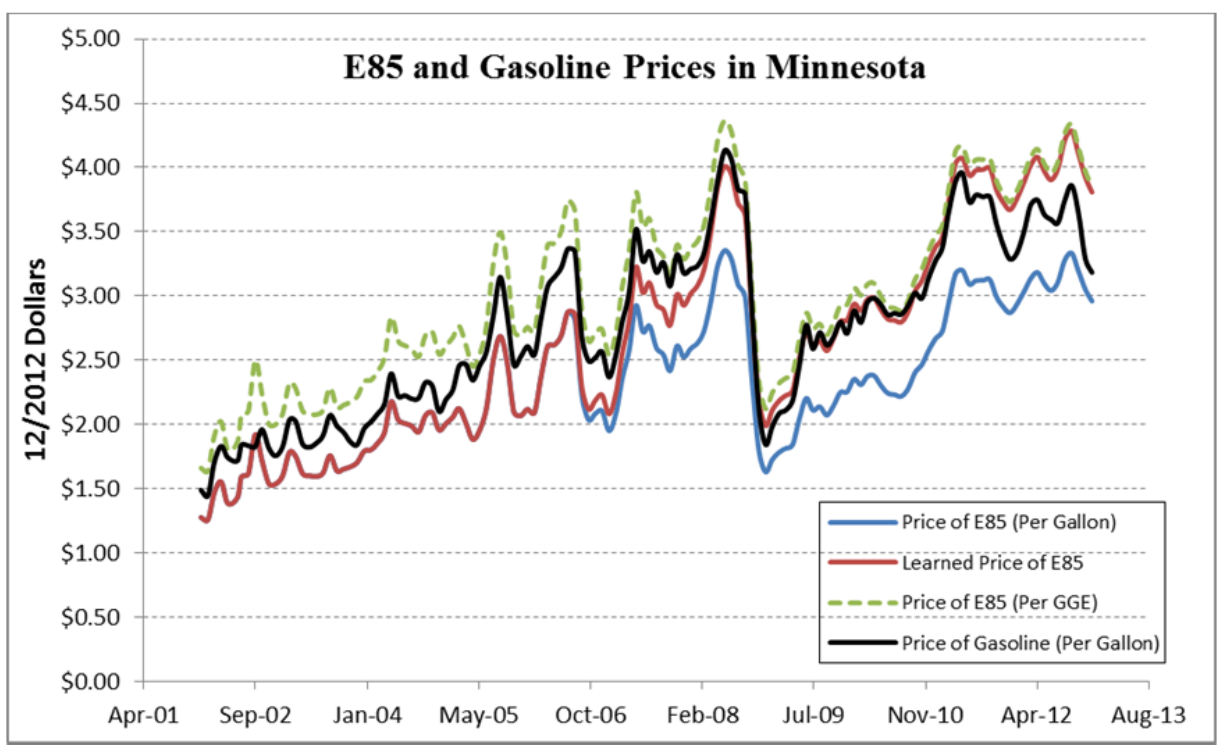

Figure 7. E85 and Gasoline Prices in Minnesota.

Minnesota's data proved to be the most useful for statistical analysis because of the length of the time series, the range of volumes and market shares of E85, and the completeness and consistency of the data base (see Appendix, table 1). The Minnesota data have been previously analyzed by Anderson $(2006,2012)$ and Greene, Zhou and Wilson (2009). None of those three studies used data more recent than 2008. Anderson's analyses are based on station level sales data and do not directly estimate the effect of E85 availability on a state or regional basis. Greene, Zhou and Wilson is based on aggregate monthly data for the entire state of Minnesota. E85 availability was based on the ratio of stations offering E85 to total gasoline refueling stations. The analysis described below further advances the work by Greene, Zhou and Wilson (2009) using most recent state-level dataset of Minnesota, North Dakota and Iowa.

Equation 6 can be re-written in the following form:

$$
\ln \left(\frac{s_{E t}}{s_{G t}}\right)=A_{0}+A_{1 E} P_{E t}+A_{1 G} P_{G t}+A_{2} \exp \left(A_{3} f_{E t}\right)+A_{4} \ln \left(\frac{s_{E t-1}}{s_{G t-1}}\right) .
$$

\footnotetext{
${ }^{1}$ The script enumerates $\alpha$ in the range of 0 to 0.05 with an interval of 0.001 .
} 
Additional monthly (quarterly for the case of Iowa data) fixed effects variables are included in equation 9 to account for possible seasonality of E85 demand. The fact that the dependent variable is the log of the ratio of E85 and gasoline shares should remove seasonality common to both fuels. Estimation of the E85 choice equation 9 poses two interdependent challenges: (1) determining whether E85 price and E85 choice are simultaneously determined, and (2) estimation of the non-linear fuel availability function. Estimation of nonlinear simultaneous equations is challenging and in this case proved not to be possible due to the inability of the estimation algorithm to converge. This is unfortunate because an accurate estimate is important for estimating the coefficients for fuel availability and is also important to a valid test of simultaneity. The approach taken was to estimate the slope of the exponential availability cost function using NLS. We then used a fixed value of availability slope in subsequent estimations and tests.

It is arguable whether E85 price is exogenous to the model or not. On one hand E85 prices could be exogenous because they are chiefly determined by the wholesale prices of ethanol and gasoline, and those prices are determined in much larger markets. However, it is a possibility that shocks to demand or supply could affect monthly market prices of E85. Endogeneity of E85 prices, if not properly accounted for, could result in biased coefficient estimates. The Hausman test for endogeneity was conducted and the model was estimated using both NLS and 2SLS.

Coefficient estimates and their standard errors are summarized in Table 1. More detailed results can be found in the Appendix, tables 2-4. Wholesale gasoline and E85 prices and their oneperiod lagged values were used as instrumental variables for the Hausman test and 2SLS estimation. It is highly likely that these variables satisfy the two important criteria for instrumental variables: (1) because E85 prices are largely determined by wholesale ethanol and gasoline prices the instruments are correlated with the E85 price (verified by the test), and (2) wholesale ethanol and gasoline prices are essentially exogenous to the model as explained by Anderson (2012). The Hausman test did not reject the null hypothesis of exogenous prices for North Dakota and Iowa, with p-values of 0.81 and 0.75 , respectively. However, the test rejects the null hypothesis for Minnesota ( $\mathrm{p}$-value of 0.0076) when the learned price variable is used. On the other hand, the null hypothesis of exogeneity of the price of E85 cannot be rejected (p-value: 0.14 ) if either volumetric or energy equivalent E85 prices are used in the model estimation. Fortunately, the issue of E85 price endogeneity has little impact on model prediction: the long-run coefficients of the 2SLS estimates are very close to those of the NLS estimates.

The fit of the model to the Minnesota and Iowa data is good, with an adjusted R-squared more than 0.97. But the fit of the model to North Dakota is only moderate, with an adjusted R-squared about 0.81 . This could be due to the relatively short length of North Dakota time series. In addition, it is likely that E85 demand in North Dakota differs from that of Minnesota and Iowa in that the majority of E85 use appears to come from fleets subject to alternative fuel regulations (see Figure 2). Data quality and consistency might also be issues. 
Table 1. Choice Equation Estimation Results for Minnesota (seasonal effects estimates have been omitted for simplicity; values in parentheses are standard errors)

\begin{tabular}{l|c|c|c|c|c|c}
\hline \multirow{2}{*}{\multicolumn{1}{c|}{ Variable }} & \multicolumn{2}{|c|}{ MN } & \multicolumn{2}{c|}{ ND } & \multicolumn{2}{c}{ IA } \\
\cline { 2 - 7 } & NLS & 2SLS & NLS & 2SLS & NLS & 2SLS \\
\hline Constant & -0.91 & -1.38 & -3.08 & -3.09 & -2.32 & -2.59 \\
& $(0.13)$ & $(0.25)$ & $(0.63)$ & $(6.35)$ & $(0.37)$ & $(0.95)$ \\
\hline $\mathrm{P}_{\mathrm{G}}$ & 0.96 & 1.57 & 0.66 & 0.63 & 1.13 & 1.40 \\
& $(0.11)$ & $(0.29)$ & $(0.17)$ & $(0.21)$ & $(0.20)$ & $(0.89)$ \\
\hline $\mathrm{P}_{\mathrm{E}}$ & -0.85 & -1.42 & -0.32 & -0.27 & -1.08 & -1.36 \\
& $(0.10)$ & $(0.27)$ & $(0.19)$ & $(0.26)$ & $(0.20)$ & $(0.92)$ \\
\hline Availability slope & -1.20 & -2.17 & $-3.21 \mathrm{E}-06$ & $-3.46 \mathrm{E}-6$ & -2.50 & -2.60 \\
& $(0.19)$ & $(0.47)$ & $(2.07 \mathrm{E}-6)$ & $(2.33 \mathrm{E}-6)$ & $(0.65)$ & $(0.75)$ \\
\hline Availability exponent & -18.83 & -18.83 & 104.4 & 104.4 & -200 & -200 \\
& $(7.30)$ & $(\mathrm{n} . \mathrm{a})$. & $(113.3)$ & $(\mathrm{n} . \mathrm{a})$. & $(51.78)$ & $(\mathrm{n} . \mathrm{a})$. \\
\hline Dependent variable (t-1) & 0.63 & 0.37 & 0.45 & 0.45 & 0.42 & 0.37 \\
& $(0.05)$ & $(0.12)$ & $(0.11)$ & $(0.11)$ & $(0.09)$ & $(0.19)$ \\
\hline Number of observations & 131 & 131 & 65 & 65 & 35 & 35 \\
\hline Adjusted R-squared & 0.9803 & 0.9747 & 0.8097 & 0.8095 & 0.9759 & 0.9742 \\
\hline Hausman test p-value & & 0.007614 & & 0.813829 & & 0.75473 \\
\hline
\end{tabular}

Notes: 2SLS estimates are conditional on the value of A3 (availability exponent) obtained in NLS estimation.

The intercept terms in all three datasets are significant and negative, indicating a general preference for gasoline at equal prices and availability. Dividing the intercepts by the price coefficient produces a value in dollars per gallon of just over $\$ 1$ for Minnesota and more in Iowa and North Dakota. The intercepts might reflect unfamiliarity with E85 or the nuisance of greater refueling frequency when using E85 (due to reduced vehicle range per tank). However, they may also reflect shortcomings of the model, in particular an imperfect representation of the cost of fuel availability, discussed below.

Anderson (2012) used the difference between E85 and E10 prices as the main price variable in his model. This requires that the individual price coefficients be equal and opposite in sign. This hypothesis was tested by estimating the price coefficients for E85 and gasoline separately. Detailed test results are provided in tables 5-7 of the Appendix. The hypothesis of equal and opposite signs cannot be rejected for Iowa but is rejected for Minnesota and North Dakota. The short-run and long-run own price elasticities of E85 choice, assuming a price per gasoline equivalent gallon of $\$ 3.25$ and a market share of $5 \%$, are summarized in table 2 . The short-run (one month) elasticity is calculated according to the following:

$$
\beta=A_{1} P_{E}\left(1-s_{E}\right)
$$


The presence of the lagged dependent variable implies a process of dynamic adjustment in which the response to prices over the period of a year or so will be greater. The long-run price elasticity is greater by a factor of 1/(1-adjustment rate) (Hamilton,1994), where the adjustment rate is the coefficient for the lagged dependent variable. In general, the 2SLS estimates have higher short-run price elasticities than the NLS estimates. The NLS estimate of the short run price elasticity for Minnesota, for example, is about 50\% greater the 2SLS estimate. The longrun own price elasticity of the 2SLS estimates, on the other hand, is very close to that of the NLS estimates. This is because the 2SLS estimates imply that the adjustment process is more rapid as evidenced by the coefficient of lagged dependent variable of 0.37 in comparison to 0.63 in the NLS estimates. At the end of a 6-month period the adjustment process would be $100 \%$ complete according to the 2SLS estimate and $96 \%$ complete based on the NLS estimate and the long run price responses would be almost equal.

Price elasticities derived from the North Dakota dataset are smallest among the three datasets. Again, this is likely due to the fact that the majority of E85 use in North Dakota appears to be by regulated fleets, and fleet-demand is less sensitive to price. Elasticities for Minnesota are somewhat larger than for Iowa: the short-run values are -4.4 for Minnesota (2SLS estimates) and -3.3 for Iowa (NLS estimates) while the long-run values are -7.0 (2SLS estimates) for Minnesota and -5.7 for Iowa (NLS estimates). Elasticities for Minnesota are highest, possibly indicating Minnesota has the largest proportion of non-fleet E85 use and consequently has the highest sensitivity to price.

Table 2. Short-run and Long-run Own Price Elasticity of E85 Choice

\begin{tabular}{l|c|c|c|c|c|c}
\hline & \multicolumn{2}{|c|}{ MN } & \multicolumn{2}{c|}{ ND } & \multicolumn{2}{c}{ IA } \\
\cline { 2 - 6 } & NLS & 2SLS & NLS & 2SLS & NLS & 2SLS \\
\hline $\begin{array}{l}\text { Short-run E85 price } \\
\text { elasticity (5\%, \$3.25/gal) }\end{array}$ & -2.6 & -4.4 & -1.0 & -0.8 & -3.3 & -4.2 \\
\hline $\begin{array}{l}\text { Long-run E85 price } \\
\text { elasticity (5\%, \$3.25/gal) }\end{array}$ & -7.1 & -7.0 & -1.8 & -1.5 & -5.7 & -6.7 \\
\hline
\end{tabular}

The coefficients of fuel availability (availability slope A2 and availability exponent A3 in equation 9) vary greatly across the three states. The availability exponent for North Dakota has a wrong sign and is not statistically significant. Although the availability exponent for Iowa is statistically significant, its value is -200 , implying that the cost of fuel availability decays very quickly as the fraction of stations offering E85 increases. It is not clear whether these coefficient estimates provide true insights regarding the role of fuel availability in E85 choice in North Dakota and Iowa or they are due to shortcomings in the model formulation or data. Coefficient estimates for Minnesota appear more plausible. The implied cost of fuel availability at different ratios of E85 stations to gasoline stations is shown in Figure 8. At 1\% availability the penalty is approximately $\$ 1.3$ per gallon and decreases rapidly to about $\$ 0.2$ per gallon at $10 \%$ and becomes effectively zero when the availability of E85 exceeds $30 \%$ of the availability of 
gasoline. The cost of limited fuel availability calculated from 2SLS estimates is almost identical to that based on the NLS estimates.

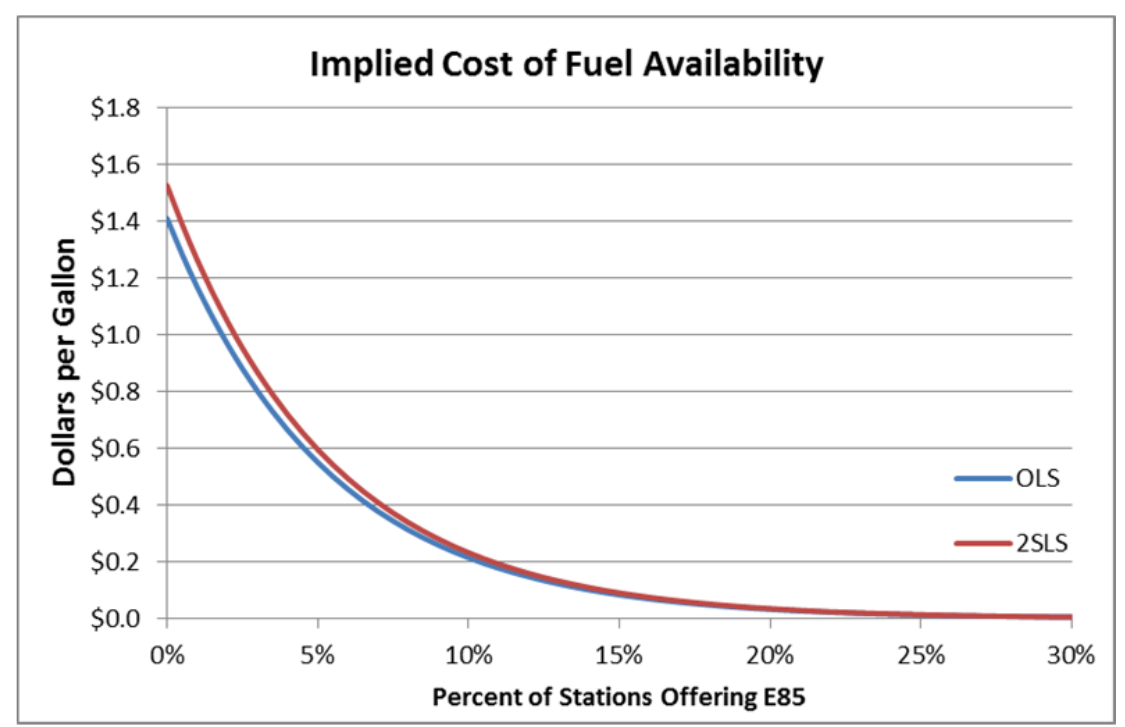

Figure 8. Cost of Limited Fuel Availability in Minnesota Implied by NLS and 2SLS Estimates.

Residual autocorrelation is often a problem in time series regressions. We initially estimated equation 7 without including the lagged dependent variable. Although the estimates had a relatively high R-squared, the residuals demonstrated a clear pattern of serial correlations (see Figure 9). A formal Breusch-Godfrey test for the Minnesota residuals confirmed this observation.

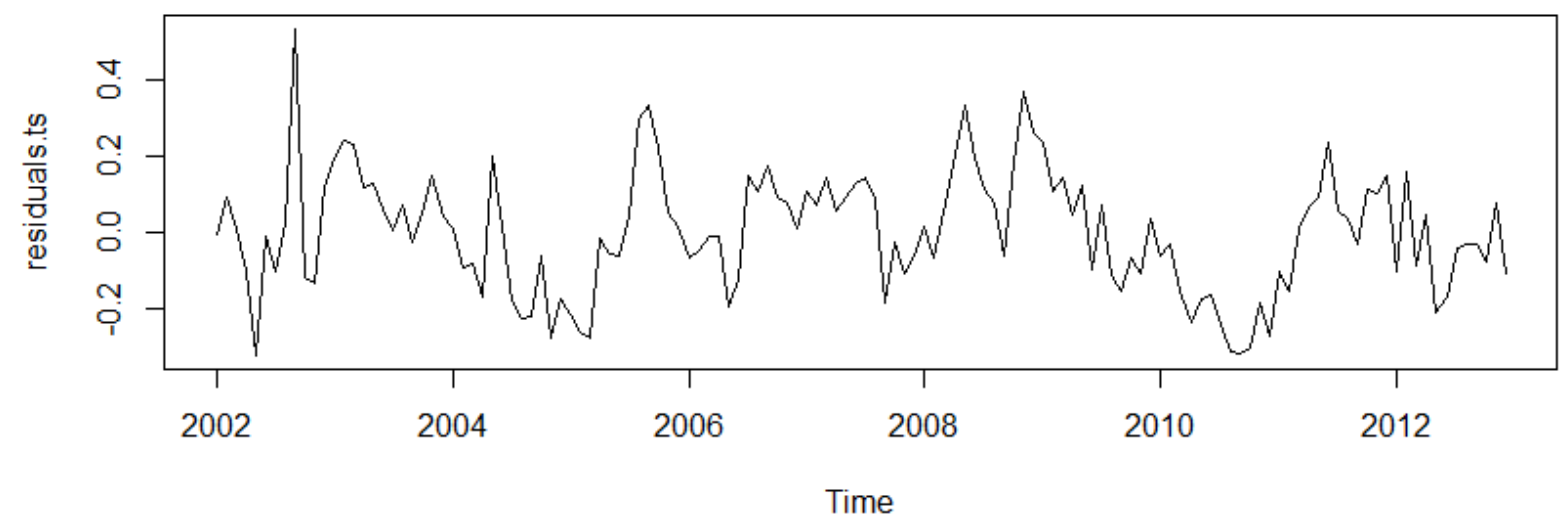

Figure 9. Regression Residuals in Original Minnesota Model.

Breusch-Godfrey test for serial correlation of order up to 2

Lagrange multiplier test $=46.2736$, degrees of freedom $=2, p$-value $=8.95 \mathrm{e}-11$ 
The existence of autocorrelation makes least squares estimates inefficient. We then included the lagged dependent variable in regression. Residual autocorrelation was thereby eliminated, as shown by the Breusch-Godfrey test. ${ }^{2}$

Breusch-Godfrey test for serial correlation of order up to 2

Lagrange multiplier test $=1.9464$, degrees of freedom $=2$, $p$-value $=0.3779$

Finally, an F-test was used to determine whether the regression using the learned E85 price fit the data significantly better than regressions using E85 prices based either on volume or on energy content. The test results indicated that for Minnesota and Iowa, the learned price was preferred but for North Dakota the regression using the learned price was not.

\footnotetext{
${ }^{2}$ If autocorrelation is not present in the residuals of a model including a lagged dependent variable, the least squares estimators remain unbiased and consistent (e.g., Greene, 1993, pp. 419-420).
} 


\section{PROPOSED MODEL}

Because E85 availability and prices vary greatly across regions and their effects on demand are non-linear, we recommend estimating demand for E85 at the level of the U.S. Census Divisions used by the NEMS model. This requires having a projection for each region of: (1) the number of FFVs in operation, (2) annual miles by vehicle type (which can be assumed to be the same as conventional gasoline vehicles), (3) the fuel economy of FFVs by vehicle type, (4) prices of gasoline and E85 by region, and (5) numbers of conventional refueling stations and number offering E85 by region. Annual Energy Outlook (AEO) tables available on line provide national stocks of FFVs but not regional stocks and it is not clear whether regional stocks are maintained in the NEMS model. However, the NEMS Transportation Sector Module documentation implies that FFV stocks are tracked at the regional level (EIA, 2012). It is assumed that the number of E85 refueling stations will be specified exogenously. All the other data are already available on line for NEMS model runs.

The total quantity of energy services (in gallons of gasoline equivalent) demanded as E85 is the following (regional and car/truck subscripts are omitted to simplify the notation):

$$
Q_{E t}=s_{E t} \frac{V_{F F V, t}}{M P G_{F F V, t}} N_{F F V, t}
$$

Where $\mathrm{s}_{\mathrm{Et}}$ is given by the following long-run (one year) choice model.

$$
S_{E t}=\frac{e^{U_{E t}}}{e^{U_{E t}}+e^{U_{G t}}}
$$

and

$$
\begin{gathered}
U_{E t}=a_{0}+a_{1} P_{E t}+a_{2} \exp \left(a_{3} f\right) \\
U_{G t}=b_{1} P_{G t}
\end{gathered}
$$

Since the data from Minnesota is the most comprehensive and in our judgment the most reliable, we use the coefficients estimated from the Minnesota dataset as starting values for constructing a national E85 prediction model. Because the Hausman test shows some albeit inconclusive evidence of E85 price endogeneity, 2SLS estimates are used although this choice has very minor practical consequences: 


$$
\begin{aligned}
& \mathrm{a}_{0}=-1.38 /(1-0.37)=-2.2 \\
& \mathrm{a}_{1}=-1.42 /(1-0.37)=-2.3 \\
& \mathrm{a}_{2}=-2.17 /(1-0.37)=-3.4 \\
& \mathrm{a}_{3}=-18.83 \\
& \mathrm{~b}_{1}=-1.57 /(1-0.37)=-2.5
\end{aligned}
$$

Because the learned price has nearly completely converged on the energy equivalent price, both prices are per gallon of gasoline (E10) equivalent energy. Fuel availability is measured as a fraction, the ratio of E85 retail stations in the region to conventional gasoline retail stations. It is not recommended that the Minnesota results be used "as is" for the entire United States for the following reasons.

1. States and regions are likely to differ with respect to their inherent preferences for E85 versus conventional gasoline which would lead to different intercept terms and different sensitivities to price. Evidence from Brazilian cities (Salvo and Huse, 2013) and our own estimates (Table 1), however, suggest that price sensitivities may not vary a great deal even between quite different nations.

2. It is not entirely clear what the lagged dependent variable is representing in the choice model. One likely explanation is that it reflects habit formation by FFV owners. If this is the case, it is also likely to vary across states and regions since habit formation may be related to inherent preferences for E85 versus gasoline. If so, like point \#1, the Minnesota data may not be representative of the rest of the United States.

3. In a simple lagged adjustment formulation, such as used in the models above, it is assumed that the adjustments to changes in all explanatory variables occur at the same rate. It may not be true that adjustment to changes in fuel availability occurs at the same rate as adjustment to price changes.

4. In Minnesota, there has been substantial demand for E85 beyond that of the fleets covered by alternative fuels regulations. This does not appear to be the case in most states. It seems highly likely that non-fleet demand for E85 is more responsive to price than fleet demand, as illustrated by the smaller price elasticities in North Dakota (Table 2). Use of the Minnesota coefficients for all states is likely to overestimate price sensitivity in those states where covered fleet demand predominates.

For the above reasons, it is recommended that the model be calibrated to each region by changing the intercept term. For the United States as a whole, adding 1 to the intercept term brings the model's prediction for 2010 close to the EIA's reported estimate of national E85 use for 2010 (91.7 versus 90.3 million gallons). This is not necessarily the best calibration since we know that for at least some states the EIA estimates greatly underestimate E85 sales (Figure 2). In fact, for this reason precise calibration of the model to United States or regional data is not possible. 
Sample predictions for the calibrated national model, using the above coefficient assumptions and the 2013 AEO (EIA, 2013b) projections for input data are illustrated in Figures 10 and 11. An additional assumption is that availability of E85 in the United States increases from its current level of 2,342 stations (AFDC, 2013) at the rate of $1 \%$ per year. The calibration and assumptions are strictly for illustrative purposes. Figure 10 compares E85 and gasoline prices, along with E85 fuel availability and E85's share of the energy services used by FFV owners. The share of energy services FFV owners choose to produce using E85 ultimately rises to almost $29 \%$ with $2 \%$ nationwide availability of E85 but a price advantage of $\$ 0.70$ per gasoline equivalent gallon. The sudden increase in E85 shares from 2039 to 2040 is due to a sudden increase in E85's price advantage in 2040: from $\$ 0.48$ to $\$ 0.70$ per gge. Figure 11 shows the growth of the FFV vehicle stock and the quantity of E85 use by cars and light trucks in gasoline equivalent gallons.

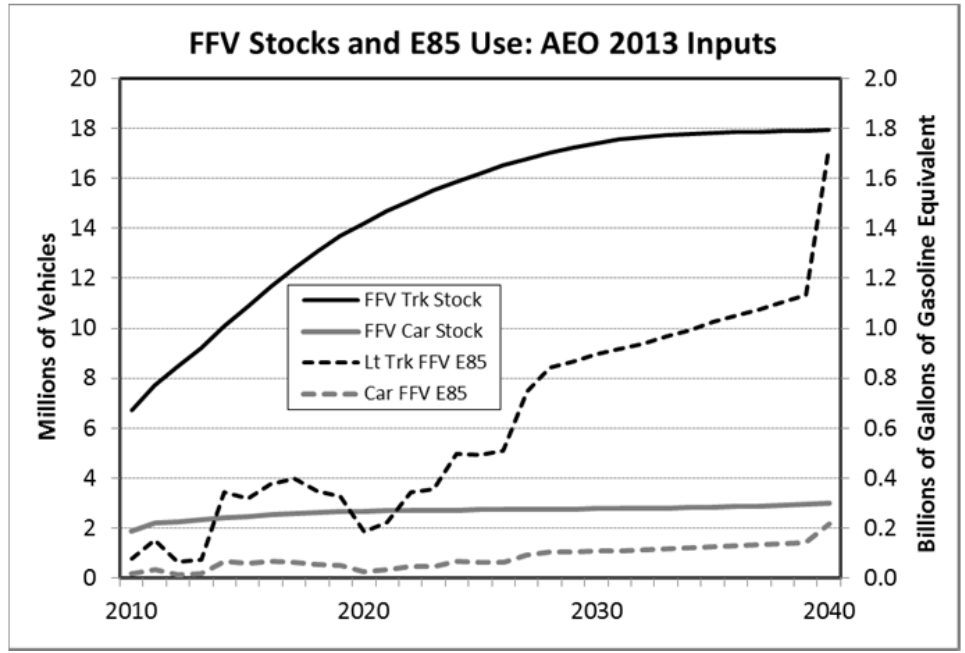

Figure 10. Fuel Prices, Availability and E85 Choice.

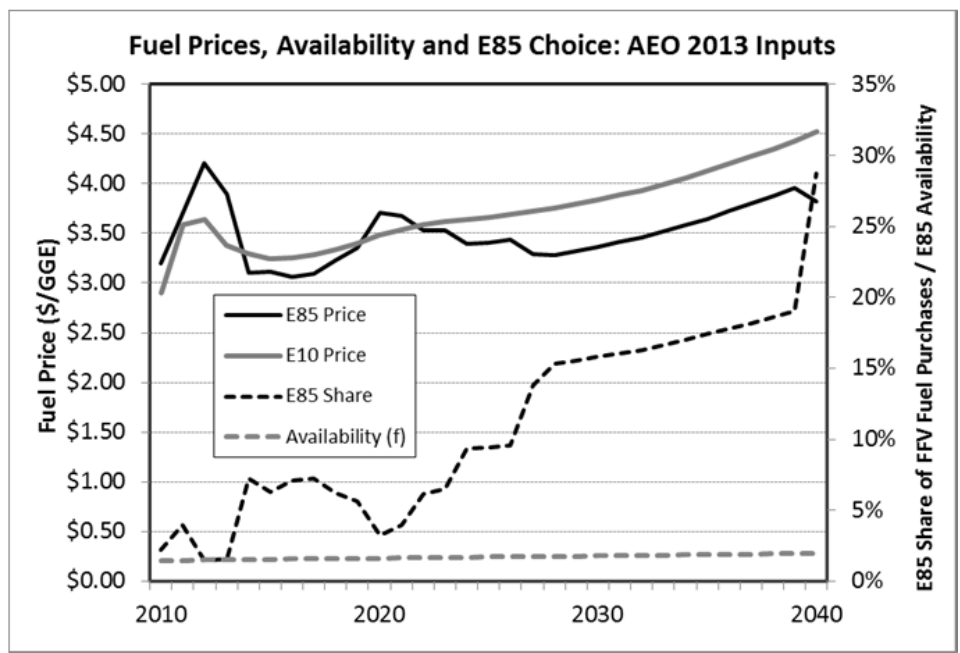

Figure 11. FFV Stocks and E85 Use: AEO 2013 Inputs. 
Calibrating a regional model requires knowing the numbers of FFVs on the road and the numbers of E85 refueling stations in each region. Estimates of the stocks of FFVs vehicles are assumed to be available in the NEMS model but are not published in the Annual Energy Outlook data tables available on the internet. ${ }^{3}$ Data on E85 and gasoline prices for 2010-2040 were obtained from the 2013 AEO Reference Case regional tables. The gasoline and E85 prices shown for 2011 in the 2013 AEO tables appear to be an anomaly. E85's typical price disadvantage relative to gasoline of about $10 \%$ per gge flips to a price advantage of about $12 \%$ in 2011 and then returns to a disadvantage of $15 \%$ in 2012. The authors know of no reason why this should have occurred in 2011, and other data sources show no such pattern (e.g., E85 Prices, 2013; AFDC, 2013). Other sources indicate that both gasoline and E85 prices in 2011 were intermediate between 2010 and 2012 prices, there being a nearly linear downward trend in the prices of both fuels from 2010 to 2012 . In the calibration below, the seemingly anomalous 2011 AEO prices were replaced by the average of the 2010 and 2012 prices. The change in prices from 2039 to 2040 is also unusual in that the price of E85 suddenly drops while that of E10 continues to rise.

The number of public and private E85 stations in the United States can be downloaded from the Alternative Fuels Data Center (AFDC) at http://www.afdc.energy.gov/fuels/ethanol_locations.html. Both public and private stations are included in the counts used in calibrating the regional model. This decision is arguable, of course, but since it is likely that most E85 use in the United States is still by regulated fleets it seems more appropriate to include the private stations those fleets are using. The downloadable data are identified by state and were grouped into U.S. Census Regions to obtain regional counts. The AFDC data were downloaded on July 9, 2013. About half of the records were updated in 2013 and all the others except one were updated in 2012.

The number of gasoline stations by state is available from the Census Bureau at: http://censtats.census.gov/cgi-bin/cbpnaic/cbpsect.pl . The 2011 data were collected by state and combined into the nine Census regions. The Census data do not precisely match other data sources and so comparability to the Minnesota data used in econometric estimation is not assured. The National Petroleum News Survey of 2011 reports 159,006 gasoline stations in the United States in 2010 (Davis, Diegel and Boundy, 2012), 43\% higher than the Census 2011 count of 110,830. The Census Bureau's distribution of gasoline stations by region, however, matches the distribution of gasoline consumption, as reported by the EIA, reasonably well (Figure 12). Still, this creates substantial uncertainty in the fraction of stations offering E85 in each region.

\footnotetext{
${ }^{3}$ Projections of FFV sales by region can be found at http://www.eia.gov/forecasts/aeo/data.cfm , and U.S. total FFV stocks are also available there. However, FFV stocks by region are not available for downloading.
} 


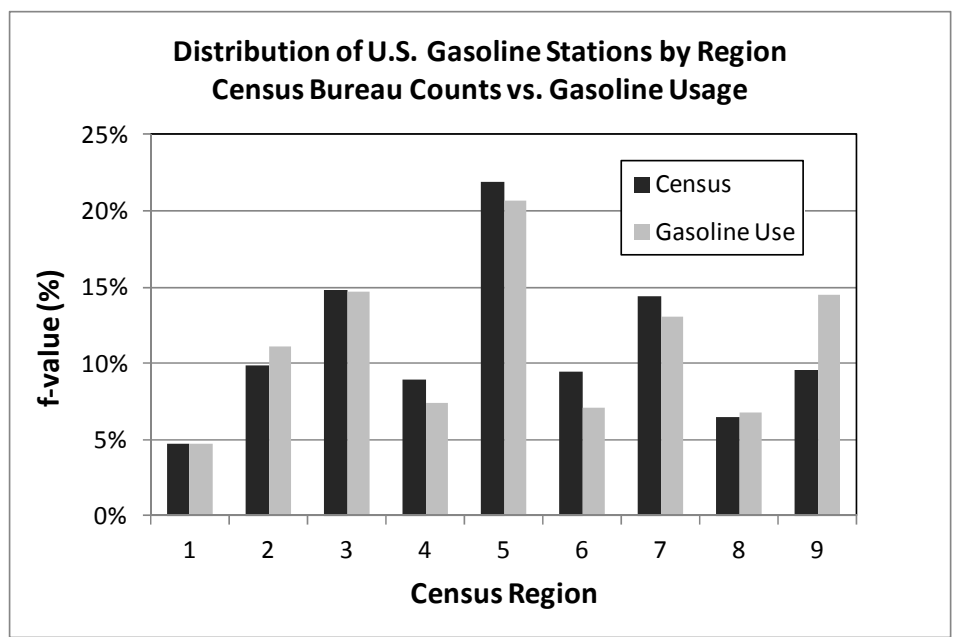

Figure 12. Distribution of U.S. Gasoline Stations by Region: Census Counts vs. Gasoline Usage.

The model's prediction, assuming an adjustment rate of 0.37 and using the national intercept term for every region is shown in Figure 13. The model's fit to the regional data is not good as indicated by an $\mathrm{R}^{2}$ value of 0.08 for a regression constrained to pass through the origin. The regional data can be fitted exactly by calculating 9 regional intercept terms. However, the EIA Survey data are believed to exclude non-fleet purchases of E85 which in some states appear to comprise a majority of E85 use. To reflect the uncertainty of both the model and regional E85 data, the calibrated regional constants are multiplied by $2 / 3$ and added to the national constant to obtain a new set of regional constants. Naturally this improves the fit of model to EIA data $\left(\mathrm{R}^{2}=\right.$ 0.67), but the match is still poor for three regions. The East and West North Central regions, in which most corn ethanol is produced, have higher predicted levels of E85 use than the EIA data. The model also predicts higher use in the Middle Atlantic region than the EIA data indicate. The fitted regression line indicates that the calibrated model typically over-predicts the EIA regional data by about $6 \%$ and the sum of the model's predictions is $10 \%$ higher than the EIA survey's national estimate. 


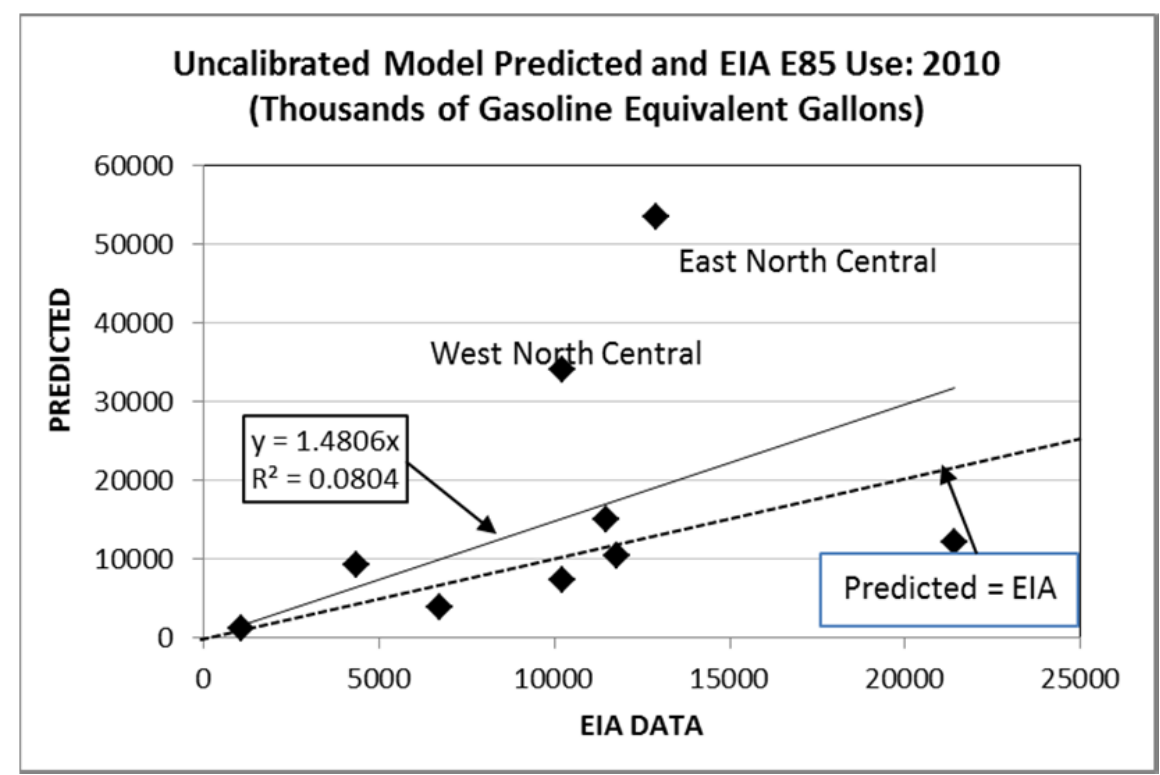

Figure 13. Predicted and EIA E85 Use for Nine Census Regions in 2010.

Because there is evidence that the EIA survey data underestimate E85 use in Minnesota and Iowa, the fact that the model over-predicts the EIA E85 use data may be appropriate. As shown in Figure 2, the EIA survey data substantially underestimate total E85 use in those two states. It is not a coincidence that these are corn ethanol-producing states in the East and West North Central regions, where $\mathrm{E} 85$ has been actively promoted and supported by public policy. Eightynine percent of U.S. ethanol production capacity is located in these two regions (Nebraska, 2013). The remaining regions have model predictions close to the EIA data as shown by the line with slope $=1$ in Figure 14. Of the remaining regions, the Middle Atlantic Region (over-prediction) and the South Atlantic Region (under-prediction) have the largest errors. 


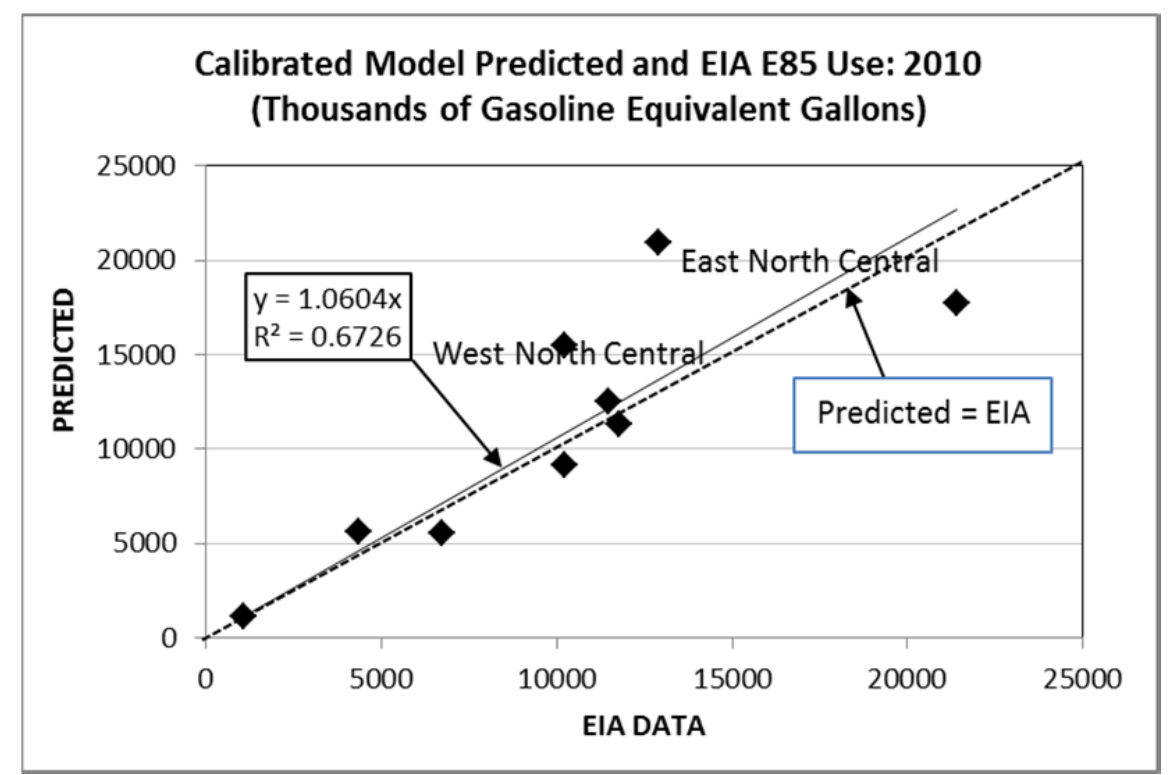

Figure 14. Calibrated Model: Predicted vs. Survey Estimate of E85 Use in 2010.

The recommended regional E85 choice model is a logit function of utility indexes that depend on E85 price and availability and on the price of gasoline (E10). The model includes regionspecific intercept terms but all other parameters are common to all regions (Table 3 ). In the future, if more reliable E85 data becomes available, it may be possible to estimate region specific price and fuel availability coefficients. The key model equations are as follows, where $\mathrm{R}$ indicates one of the nine Census regions.

Table 3. Coefficients of the Regional E85 Choice Model

\begin{tabular}{lrrrrrr}
\hline & Region & & E85 & E10 & Availability & Availability \\
Region & $\#$ & Intercept & Price & Price & Slope & Exponent \\
\hline New England & 1 & -1.25 & -2.25 & -2.49 & -3.44 & -18.83 \\
Middle Atlantic & 2 & -1.70 & -2.25 & -2.49 & -3.44 & -18.83 \\
East North Central & 3 & -2.18 & -2.25 & -2.49 & -3.44 & -18.83 \\
West North Central & 4 & -2.07 & -2.25 & -2.49 & -3.44 & -18.83 \\
South Atlantic & 5 & -0.80 & -2.25 & -2.49 & -3.44 & -18.83 \\
East South Central & 6 & -0.79 & -2.25 & -2.49 & -3.44 & -18.83 \\
West South Central & 7 & -0.96 & -2.25 & -2.49 & -3.44 & -18.83 \\
Mountain & 8 & -1.38 & -2.25 & -2.49 & -3.44 & -18.83 \\
Pacific & 9 & -1.10 & -2.25 & -2.49 & -3.44 & -18.83 \\
\hline
\end{tabular}

$$
S_{R E t}=\frac{e^{U_{R E t}}}{e^{U_{R E t}}+e^{U_{R G t}}}
$$




$$
\begin{gathered}
U_{R E t}=a_{0 R}+a_{1} P_{R E t}+a_{2} \exp \left(a_{3} f_{R}\right) \\
U_{G t R}=a_{1} P_{R G t}
\end{gathered}
$$

Finally, E85 use is estimated by multiplying the $\mathrm{E} 85$ share, $\mathrm{s}_{\mathrm{Ret}}$, number of FFVs in the region, $\mathrm{N}_{\mathrm{RFFVt}}$, by the annual energy services demand per vehicle (in gge), $\mathrm{Q}_{\mathrm{RFFVt}}$.

$$
Q_{R E t}=s_{R E t} N_{R F F V t} Q_{R F F V t}
$$

The model was tested using the regional data from the 2013 AEO Reference Case and assuming that E85 availability would increase in all regions at the rate of $1 \%$ per year. The results show E85 demand declining in most regions, despite increased availability (Figure 15). The very large difference between E85 use in the East and West North Central regions and the rest of the United States is explained by regional price differences in the AEO 2013 Reference Case. In 2040 in the East and West North Central regions E85 is $\$ 0.40$ per gge cheaper than gasoline, while in the rest of the U.S. E85 is $\$ 1.09$ to $\$ 1.10$ per gge more expensive. These prices are not entirely consistent with the AEO 2013 national price trends cited above. According to the Reference Case price projections, the economics of E85 improves over time in the two North Central regions but worsens everywhere else in the United States.

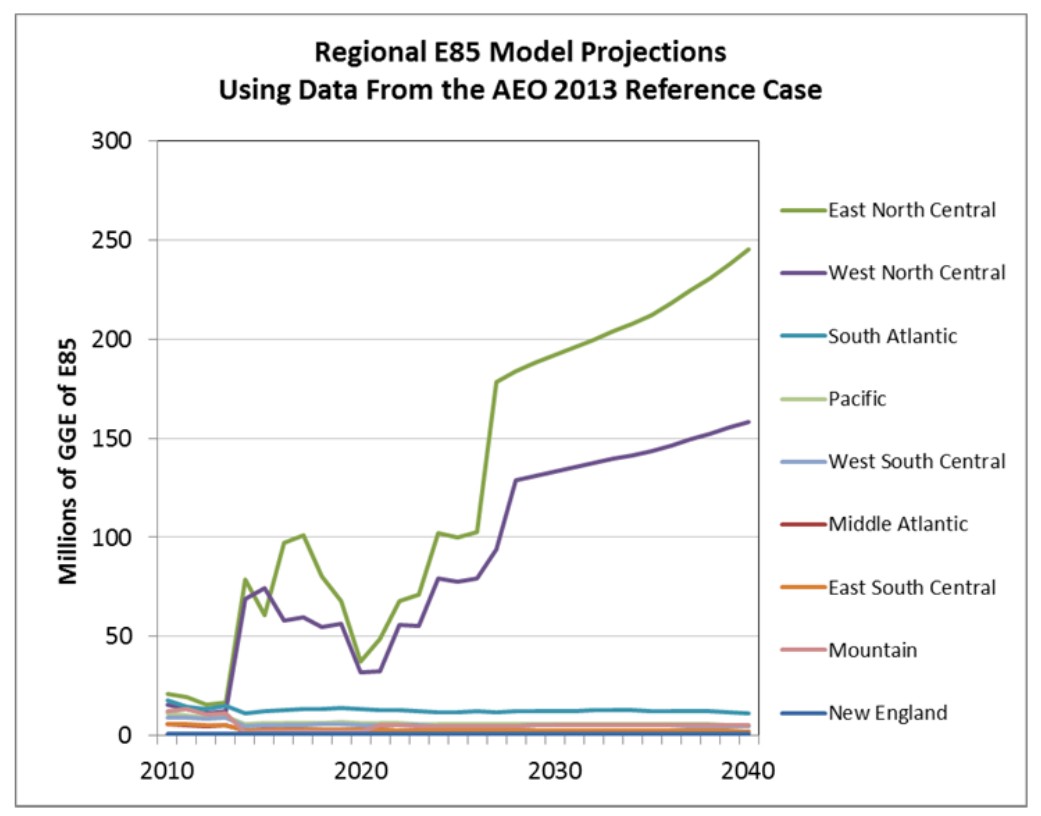

Figure 15. Regional E85 Model Projections Using Data from the AEO 2013 Reference Case. 


\section{CONCLUSIONS}

Despite the lack of accurate E85 sales data for all regions and the apparent differences between the fleet and non-fleet markets for E85, the Minnesota data provide a reasonable basis for estimating the sensitivity of E85 choice to price and availability that can inform the construction of a plausible model for projecting E85 demand at the regional level. Data from Iowa and North Dakota are considered to provide less reliable estimates for the following reasons:

1. The proportion of E85 use by fleets subject to alternative fuel regulations appears to be large,

2. The data on prices, demand and stations offering E85 come from different sources, in general, and thus may not be as consistent as the Minnesota data,

3. The Minnesota data cover a longer period of time and include substantial variations in prices, station availability and market share, thus offering a better "sample design."

The very approximate consistency in price responsiveness in markets as different as Brazil as Minnesota suggest that it is reasonable to use price coefficient estimates derived from Minnesota for other regions of the United States. This method, however, falls far short of ideal and should be improved in the future, if possible. Over time, as more data become available it may be possible to update and refine the current parameter estimates.

It appears that choice of E85 can be explained by relatively few variables:

1. Price of E85

2. Price of $\mathrm{E} 10$

3. Ratio of stations offering E85 to total gasoline outlets

4. Number of FFVs on the road

Choice of E85 appears to be highly price elastic. The elasticities inferred in this study are somewhat higher than those of previous econometric analyses. However, this is consistent with the greater preponderance of non-fleet (public) E85 sales in the more recent Minnesota data. It is also consistent with the observation that, for FFV owners, E85 and E10 are close substitutes. Controlling for prices and availability (as the model attempts to do), the only practical difference is the lower energy content of E85.

Although the estimated effect of fuel availability is plausible and very approximately consistent with evidence from previous studies, it is far from definitive. Not only do estimates vary greatly across the three states but it was not possible to estimate the availability exponent using 2SLS. This is unfortunate because fuel availability is a critical factor in the early market development 
of alternative fuels. Further research is needed on the value of fuel availability not only for E85 but for other alternative fuels, as well.

Despite these limitations, it appears that a reasonable regional model of E85 choice can be constructed that relies on data available in NEMS projections plus estimates of E85 availability. Initial testing of the model produced plausible projections, however, some issues with the AEO 2013 prices arose. The plausibility of the model's projections can be attributed to the constraints imposed by the number of FFVs on the road and fuel availability. Unfortunately, we cannot be confident that fuel availability costs are accurately characterized in critical regions from 10-20\%. The model's predictions will also be very sensitive to E85 and E10 prices. Price sensitivity will create volatility in projections of E85 demand if the price difference changes suddenly but such volatility is very likely a realistic market response. Further testing within the NEMS framework is needed. However, we believe that the regional E85 demand model is likely to perform plausibly. 


\section{REFERENCES}

1. (AFDC) Alternative Fuels Data Center. (2013). "Ethanol Refueling Station Locations," http://www.afdc.energy.gov/fuels/ethanol locations.html and "Alternative Fuel Price Report," http://www.afdc.energy.gov/fuels/prices.html , July 12, 2013.

2. Anderson, S.T. (2012). "The Demand for Ethanol as a Gasoline Substitute," Journal of Environmental Economics and Management, vol. 63, no. 2, pp. 151-168.

3. Anderson, S.T. (2006). "The Demand for E85 Ethanol," University of California Energy Institute, Annual Research Conference on Gasoline and Oil Markets, Berkeley, California, November 13, 2006. http://www.ucei.berkeley.edu/gasoilmarkets/Papers/2Anderson.pdf.

4. Davis, S.C., S.W. Diegel and R.G. Boundy. (2012). Transportation Energy Data Book Edition 31, ORNL-6987, Oak Ridge National Laboratory, Oak Ridge, Tennessee.

5. E85 Prices. (2013). "National E85 Price Spread," http://e85prices.com/, July 12, 2013.

6. (EIA) Energy Information Administration. (2012). Transportation Sector Module of the National Energy Modeling System: Model Documentation, October 2012, http://www.eia.gov/forecasts/nemsdoc/transportation/pdf/m070(2012).pdf.

7. (EIA) Energy Information Administration. (2013a). Alternative Fuel Vehicle Data, Renewable and Alternative Fuels, http://www.eia.gov/renewable/afv/users.cfm .

8. (EIA) Energy Information Administration. (2013b). Annual Energy Outlook 2013, Data Tables, Reference Case, Transportation Demand Sector, http://www.eia.gov/forecasts/aeo/data.cfm .

9. (EPA) Environmental Protection Agency. (2013). "E15 (a blend of gasoline and ethanol)," Transportation and Air Quality, Fuels and Fuel Additives, http://www.epa.gov/otaq/regs/fuels/additive/e15/.

10. Greene, D.L., 1989. "Motor Fuel Choice: an Econometric Analysis", Transportation Research A, vol. 23A, no. 3, pp. 243-254.

11. Greene, D.L., J.Zhou and W.T. Wilson. (2009). "Consumer Choice of E85: Lessons Pfrom Minnesota's Experience," presented at the $88^{\text {th }}$ Annual Meeting of the Transportation Research Board, January 11-15, Washington, DC.

12. Greene, W.H. (1993). Econometric Analysis, $2^{\text {nd }}$ Ed., Prentice Hall, Inc., Englewood Cliffs, New Jersey.

13. Hamilton, J.D. (1994). Time Series Analysis, Princeton University Press, NJ.

14. (NRC) National Research Council. (2011). Renewable Fuel Standard, Committee on the Potential Economic and Environmental Effects of U.S. Biofuel Policy, National Academies Press, Washington, DC.

15. Nebraska Governor's Office. (2013). "Ethanol Facilities' Capacity by State," operating production as of September 2012, http://www.neo.ne.gov/statshtml/121.htm .

16. Phillips, O.R. and D.P. Schutte, 1988. "Identifying Profitable Self-Service Markets: A Test in Gasoline Retailing”, Applied Economics, vol. 20, February, pp. 263-272. 
17. Salvo, A. and C. Huse. (2013). "Build It, But Will They Come? Evidence from Consumer Choice between Gasoline and Sugarcane Ethanol," Journal of Environmental Economics and Management, article in press, http://dx.doi.org/10.1016/j.jeem.2013.04.001.

18. Schill, S.R. (2012). "GM, Ford Announce E15 Compatibility With New Models," Ethanol Producer Magazine, October 9, 2012, http://ethanolproducer.com/articles/9195/gm-ford-announce-e15-compatibility-with-newmodels .

19. Thomas, J.F., S.P. Huff and B.H. West. (2012). Fuel Economy and Emissions of a Vehicle Equipped with an Aftermarket Flexible-Fuel Conversion Kit, ORNL/TM2011/483, Oak Ridge National Laboratory, Oak Ridge, Tennessee.

20. Train, K. (1993). Qualitative Choice Analysis, $3^{\text {rd }}$ printing, MIT Press, Cambridge, MA. 


\section{APPENDIX}

Table 1. Variables and Data Sources

\begin{tabular}{|c|c|}
\hline Variables & Source \\
\hline E85 sales & $\begin{array}{l}\text { - MN: monthly data from Minnesota Dept. of Commerce, } \\
\text { http://mn.gov/commerce/energy/images/E85-Fuel-Use-Annual-Data.pdf } \\
\text { IA: monthly data (Jan 2004-Dec 2005) from Iowa Renewable Fuel } \\
\text { Association, http://www.iowarfa.org/resources statistics.php and } \\
\text { Quarterly data (2006-2012) from Iowa tax report: } \\
\text { http://www.iowa.gov/tax/forms/motor.html\#Monthly. } \\
\text { ND: monthly data (July 2007 - Dec 2012), personal communications } \\
\text { with Doug Arndt (1arndt@nd.gov) at Office of ND State Tax } \\
\text { Commissioner }\end{array}$ \\
\hline E85 retail price & $\begin{array}{l}\text { - MN: monthly data from Minnesota Dept. of Commerce, } \\
\text { http://mn.gov/commerce/energy/images/E85-Fuel-Use-Annual-Data.pdf } \\
\text { - } \mathrm{IA} \text { and ND: daily data from www.e85prices.com }\end{array}$ \\
\hline \# of E85 stations & $\begin{array}{l}\text { MN: monthly data from Minnesota Dept. of Commerce, } \\
\text { http://mn.gov/commerce/energy/images/E85-Fuel-Use-Annual-Data.pdf } \\
\text { IA: monthly data (Jan 2004 - Dec 2005) from Iowa Renewable Fuel } \\
\text { Association, http://www.iowarfa.org/resources_statistics.php,_July } 2006 \\
\text { station count from personal communications with Grant Menke } \\
\text { (gmenke@iowarfa.org)_and_monthly data (June 2007 - Dec 2012) from } \\
\text { DOE Alternative Fuel Data Center, personal communications with } \\
\text { Alexis Schayowitz (technicalresponse@icfi.com) } \\
\text { ND: monthly data (July 2007 - Dec 2012) from DOE Alternative Fuel } \\
\text { Data Center, personal communications with Alexis Schayowitz } \\
\text { (technicalresponse@icfi.com) }\end{array}$ \\
\hline Gasoline sales & $\begin{array}{l}\text { Monthly data from Federal Highway Administration (FHWA), } \\
\text { http://www.fhwa.dot.gov/policyinformation/motorfuelhwy trustfund.cfm }\end{array}$ \\
\hline $\begin{array}{l}\text { Gasoline retail } \\
\text { price }\end{array}$ & $\begin{array}{l}\text { Monthly data from EIA, } \\
\text { http://www.eia.gov/dnav/pet/pet pri gnd a epm0 pte dpgal m.htm }\end{array}$ \\
\hline $\begin{array}{l}\text { \# of gasoline } \\
\text { stations }\end{array}$ & $\begin{array}{l}\text { Annual counts from the magazine National Petroleum News (June } 1 \text { snapshot, } \\
2002 \text {-2012) }\end{array}$ \\
\hline \# of FFVs & Annual data (Jan 1 snapshot, 2002-2013) from RL Polk and company \\
\hline \# of total vehicles & Annual data (Jan 1 snapshot, 2002-2013) from RL Polk and company \\
\hline $\begin{array}{l}\text { Gasoline } \\
\text { wholesale price }\end{array}$ & $\begin{array}{l}\text { Monthly data from EIA, } \\
\text { http://www.eia.gov/dnav/pet/pet pri allmg a epm0 pwa dpgal m.htm }\end{array}$ \\
\hline $\begin{array}{l}\text { E85 wholesale } \\
\text { price }\end{array}$ & $\begin{array}{l}\text { Monthly data from Nebraska Energy Office, } \\
\text { http://www.neo.ne.gov/statshtml/66.html }\end{array}$ \\
\hline CPI & $\begin{array}{l}\text { http://www.inflationdata.com/Inflation/Consumer_Price_Index/HistoricalCPI.as } \\
\text { px?reloaded=true }\end{array}$ \\
\hline
\end{tabular}


Table 2a. NLS Regression Estimates of MN E85 Choice Equation

\begin{tabular}{lrrrc}
\hline Coefficients & Estimate Std. & Error t & Value & $\operatorname{Pr}(>/ \mathrm{t} /)$ \\
\hline (Intercept) & -0.910157 & 0.125990 & -7.224 & $5.91 \mathrm{e}-11$ \\
Pg & 0.958119 & 0.109799 & 8.726 & $2.38 \mathrm{e}-14$ \\
Pe85 & -0.848934 & 0.100712 & -8.429 & $1.15 \mathrm{e}-13$ \\
A2 & -1.197474 & 0.193633 & -6.184 & $9.82 \mathrm{e}-09$ \\
A3 & -18.827704 & 7.296044 & -2.581 & 0.0111 \\
Ln(se,t-1/sg,t-1) & 0.628019 & 0.049624 & 12.656 & $<2 \mathrm{e}-16$ \\
Season_Feb & 0.056143 & 0.047690 & 1.177 & 0.2415 \\
Season_Mar & 0.111591 & 0.047959 & 2.327 & 0.0217 \\
Season_Apr & 0.126454 & 0.048286 & 2.619 & 0.0100 \\
Season_May & 0.037301 & 0.048769 & 0.765 & 0.4459 \\
Season_Jun & 0.022485 & 0.048678 & 0.462 & 0.6450 \\
Season_Jul & 0.002098 & 0.048880 & 0.043 & 0.9658 \\
Season_Aug & 0.016461 & 0.048751 & 0.338 & 0.7362 \\
Season_Sep & 0.032448 & 0.048588 & 0.668 & 0.5056 \\
Season_Oct & 0.018694 & 0.048364 & 0.387 & 0.6998 \\
Season_Nov & -0.027067 & 0.048917 & -0.553 & 0.5811 \\
Season_Dec & -0.047511 & 0.048276 & -0.984 & 0.3271 \\
\hline
\end{tabular}

Residual standard error: 0.109 on 115 degrees of freedom Multiple R-squared: 0.9826,Adjusted R-squared: 0.9803

F-statistic: 432.2 on 15 and $115 \mathrm{DF}$, p-value: $<2.2 \mathrm{e}-16$

Table 2b. 2SLS Regression Estimates of MN E85 Choice Equation

\begin{tabular}{lccrc}
\hline Coefficients & Estimate Std. & Error t & Value & $\operatorname{Pr}(>/ \mathrm{t} /)$ \\
\hline (Intercept) & -1.375712 & 0.245267 & -5.609 & $1.42 \mathrm{e}-07$ \\
Pg & 1.569483 & 0.289956 & 5.413 & $3.43 \mathrm{e}-07$ \\
Pe85 & -1.424161 & 0.271568 & -5.244 & $7.23 \mathrm{e}-07$ \\
A2 & -2.171999 & 0.471627 & -4.605 & $1.07 \mathrm{e}-05$ \\
Ln(se,t-1/sg,t-1) & 0.373005 & 0.122868 & 3.036 & 0.00297 \\
Season_Feb & 0.047596 & 0.054157 & 0.879 & 0.38131 \\
Season_Mar & 0.099095 & 0.054600 & 1.815 & 0.07214 \\
Season_Apr & 0.134328 & 0.054811 & 2.451 & 0.01576 \\
Season_May & 0.050470 & 0.055542 & 0.909 & 0.36542 \\
Season_Jun & 0.033409 & 0.055350 & 0.604 & 0.54731 \\
Season_Jul & 0.023813 & 0.056157 & 0.424 & 0.67232 \\
Season_Aug & 0.030456 & 0.055558 & 0.548 & 0.58463 \\
Season_Sep & 0.046688 & 0.055387 & 0.843 & 0.40101 \\
Season_Oct & 0.050088 & 0.056423 & 0.888 & 0.37654 \\
Season_Nov & 0.033105 & 0.061124 & 0.542 & 0.58914 \\
Season_Dec & -0.002833 & 0.057949 & -0.049 & 0.96109 \\
\hline
\end{tabular}

Residual standard error: 0.1235 on 115 degrees of freedom

Multiple R-squared: 0.9776,Adjusted R-squared: 0.9747

F-statistic: 334.9 on 15 and $115 \mathrm{DF}$, p-value: $<2.2 \mathrm{e}-16$ 
Table 3a. NLS Regression Estimates of ND E85 Choice Equation

\begin{tabular}{lcccc}
\hline Coefficients & Estimate Std. & Error t & Value & $\operatorname{Pr}(>/ \mathrm{t} /)$ \\
\hline (Intercept) & $-3.082 \mathrm{e}+00$ & $6.345 \mathrm{e}-01$ & -4.857 & $1.26 \mathrm{e}-05$ \\
Pg. & $6.570 \mathrm{e}-01$ & $1.684 \mathrm{e}-01$ & 3.901 & 0.000292 \\
Pe85 & $-3.154 \mathrm{e}-01$ & $1.911 \mathrm{e}-01$ & -1.650 & 0.105344 \\
A2 & $-3.205 \mathrm{e}-06$ & $2.066 \mathrm{e}-06$ & -1.551 & 0.127286 \\
A3 & $1.044 \mathrm{e}+02$ & $1.133 \mathrm{e}+02$ & 0.922 & 0.361347 \\
Ln(se,t-1/sg,t-1) & $4.493 \mathrm{e}-01$ & $1.105 \mathrm{e}-01$ & 4.067 & 0.000172 \\
Season_Feb & $1.044 \mathrm{e}-02$ & $1.296 \mathrm{e}-01$ & 0.081 & 0.936087 \\
Season_Mar & $1.428 \mathrm{e}-02$ & $1.348 \mathrm{e}-01$ & 0.106 & 0.916074 \\
Season_Apr & $1.683 \mathrm{e}-01$ & $1.364 \mathrm{e}-01$ & 1.234 & 0.223187 \\
Season_May & $9.982 \mathrm{e}-02$ & $1.335 \mathrm{e}-01$ & 0.748 & 0.458128 \\
Season_Jun & $-2.843 \mathrm{e}-02$ & $1.325 \mathrm{e}-01$ & -0.215 & 0.830988 \\
Season_Jul & $-1.191 \mathrm{e}-02$ & $1.309 \mathrm{e}-01$ & -0.091 & 0.927904 \\
Season_Aug & $-2.584 \mathrm{e}-02$ & $1.256 \mathrm{e}-01$ & -0.206 & 0.837828 \\
Season_Sep & $1.187 \mathrm{e}-01$ & $1.273 \mathrm{e}-01$ & 0.932 & 0.355685 \\
Season_Oct & $9.022 \mathrm{e}-02$ & $1.243 \mathrm{e}-01$ & 0.726 & 0.471453 \\
Season_Nov & $5.126 \mathrm{e}-03$ & $1.242 \mathrm{e}-01$ & 0.041 & 0.967248 \\
Season_Dec & $1.887 \mathrm{e}-01$ & $1.251 \mathrm{e}-01$ & 1.508 & 0.137969 \\
\hline
\end{tabular}

Residual standard error: 0.2033 on 49 degrees of freedom Multiple R-squared: 0.8543,Adjusted R-squared: 0.8097

F-statistic: 19.16 on 15 and $49 \mathrm{DF}$, p-value: $1.701 \mathrm{e}-15$

Table 3b. 2SLS Regression Estimates of ND E85 Choice Equation

\begin{tabular}{lcccc}
\hline Coefficients & Estimate Std. & Error t & Value & $\operatorname{Pr}(>/ \mathrm{t} /)$ \\
\hline (Intercept) & $-3.089 \mathrm{e}+00$ & $6.354 \mathrm{e}-01$ & -4.861 & $1.25 \mathrm{e}-05$ \\
Pg & $6.262 \mathrm{e}-01$ & $2.120 \mathrm{e}-01$ & 2.954 & 0.004802 \\
Pe85 & $-2.722 \mathrm{e}-01$ & $2.631 \mathrm{e}-01$ & -1.034 & 0.305991 \\
A2 & $-3.463 \mathrm{e}-06$ & $2.332 \mathrm{e}-06$ & -1.485 & 0.143936 \\
Ln(se,t-1/sg,t-1) & $4.519 \mathrm{e}-01$ & $1.110 \mathrm{e}-01$ & 4.069 & 0.000171 \\
Season_Feb & $9.419 \mathrm{e}-03$ & $1.297 \mathrm{e}-01$ & 0.073 & 0.942413 \\
Season_Mar & $1.684 \mathrm{e}-02$ & $1.353 \mathrm{e}-01$ & 0.124 & 0.901502 \\
Season_Apr & $1.726 \mathrm{e}-01$ & $1.377 \mathrm{e}-01$ & 1.254 & 0.215914 \\
Season_May & $1.047 \mathrm{e}-01$ & $1.351 \mathrm{e}-01$ & 0.775 & 0.442009 \\
Season_Jun & $-2.414 \mathrm{e}-02$ & $1.338 \mathrm{e}-01$ & -0.180 & 0.857541 \\
Season_Jul & $-1.009 \mathrm{e}-02$ & $1.312 \mathrm{e}-01$ & -0.077 & 0.939003 \\
Season_Aug & $-2.611 \mathrm{e}-02$ & $1.257 \mathrm{e}-01$ & -0.208 & 0.836288 \\
Season_Sep & $1.224 \mathrm{e}-01$ & $1.283 \mathrm{e}-01$ & 0.954 & 0.344897 \\
Season_Oct & $8.976 \mathrm{e}-02$ & $1.244 \mathrm{e}-01$ & 0.722 & 0.474011 \\
Season_Nov & $5.815 \mathrm{e}-03$ & $1.243 \mathrm{e}-01$ & 0.047 & 0.962882 \\
Season_Dec & $1.885 \mathrm{e}-01$ & $1.252 \mathrm{e}-01$ & 1.505 & 0.138724 \\
\hline
\end{tabular}

Residual standard error: 0.2034 on 49 degrees of freedom

Multiple R-squared: 0.8542,Adjusted R-squared: 0.8095

F-statistic: 19.03 on 15 and $49 \mathrm{DF}$, p-value: $1.949 \mathrm{e}-15$ 
Table 4a. NLS Regression Estimates of IA E85 Choice Equation

\begin{tabular}{lccrc}
\hline Coefficients & Estimate Std. & Error t & Value & $\operatorname{Pr}(>/ t /)$ \\
\hline (Intercept) & -2.31749 & 0.36888 & -6.283 & $1.01 \mathrm{e}-06$ \\
Pg & 1.12882 & 0.20412 & 5.530 & $7.36 \mathrm{e}-06$ \\
Pe85 & -1.08293 & 0.20202 & -5.361 & $1.16 \mathrm{e}-05$ \\
$\mathrm{~A} 2$ & -2.49888 & 0.65194 & -3.833 & 0.000687 \\
A3 & -200.0000 & 51.7840 & -3.862 & 0.000669 \\
Ln(se,t-1/sg,t-1) & 0.42001 & 0.09060 & 4.636 & $8.11 \mathrm{e}-05$ \\
Season_Q2 & 0.12958 & 0.08524 & 1.520 & 0.140077 \\
Season_Q3 & -0.03175 & 0.08905 & -0.356 & 0.724244 \\
Season_Q4 & -0.06999 & 0.08377 & -0.836 & 0.410752 \\
\hline
\end{tabular}

Residual standard error: 0.1613 on 27 degrees of freedom

Multiple R-squared: 0.9809 ,Adjusted R-squared: 0.9759

F-statistic: 197.7 on 7 and $27 \mathrm{DF}$, p-value: $<2.2 \mathrm{e}-16$

Table 4b. 2SLS Regression Estimates of IA E85 Choice Equation

\begin{tabular}{lccrc}
\hline Coefficients & Estimate Std. & Error t & Value & $\operatorname{Pr}(>/ \mathrm{t} /)$ \\
\hline (Intercept) & -2.58754 & 0.95031 & -2.723 & 0.01120 \\
Pg & 1.39600 & 0.88657 & 1.575 & 0.12699 \\
Pe85 & -1.36247 & 0.92479 & -1.473 & 0.15224 \\
A2 & -2.60431 & 0.75539 & -3.448 & 0.00187 \\
Ln(se,t-1/sg,t-1) & 0.37049 & 0.18507 & 2.002 & 0.05544 \\
Season_Q2 & 0.10160 & 0.12616 & 0.805 & 0.42767 \\
Season_Q3 & -0.03683 & 0.09360 & -0.393 & 0.69707 \\
Season_Q4 & -0.03877 & 0.13281 & -0.292 & 0.77255 \\
\hline
\end{tabular}

Residual standard error: 0.1669 on 27 degrees of freedom

Multiple R-squared: 0.9795 ,Adjusted R-squared: 0.9742

F-statistic: 181.1 on 7 and $27 \mathrm{DF}$, p-value: $<2.2 \mathrm{e}-16$

Table 5a. Test for Equal and Opposite Sign of Price Coefficients for MN NLS Model

Linear hypothesis test

Hypothesis:

$\mathrm{A} 1 \mathrm{~g}+\mathrm{A} 1 \mathrm{e}=0$

Model 1: restricted model

Model 2: $y(t)=A 0+A 1 g * P g+A 1 e^{*} \operatorname{Pe} 85+A 2 * \exp (A 3 * f)+A 4 * y(t-1)$, where $y(t)=L n(s e, t / s g, t)$

\begin{tabular}{ccccccc}
\hline & Res.Df & RSS & Df & Sum of Sq & F & $\operatorname{Pr}(>\mathrm{F})$ \\
\hline 1 & 116 & 1.5879 & & & & \\
2 & 115 & 1.3661 & 1 & 0.22184 & 18.675 & $3.31 \mathrm{e}-05$ \\
\hline
\end{tabular}


Table 5b. Test for Equal and Opposite Sign of Price Coefficients for MN 2SLS Model

Linear hypothesis test

Hypothesis:

$\mathrm{Alg}+\mathrm{Ale}=0$

Model 1: restricted model

Model 2: $y(t)=A 0+A 1 g * P g+A 1 e * P e 85+A 2 * \exp (A 3 * f)+A 4 * y(t-1)$, where $y(t)=L n(s e, t / s g, t)$

\begin{tabular}{ccccccc}
\hline & Res.Df & RSS & Df & Sum of Sq & F & $\operatorname{Pr}(>\mathrm{F})$ \\
\hline 1 & 116 & 2.0577 & & & & \\
2 & 115 & 1.7536 & 1 & 0.30406 & 19.94 & $1.878 \mathrm{e}-05$ \\
\hline
\end{tabular}

Table 6a. Test for Equal and Opposite Sign of Price Coefficients for ND NLS Model

Linear hypothesis test

Hypothesis:

$\mathrm{A} 1 \mathrm{~g}+\mathrm{A} 1 \mathrm{e}=0$

Model 1: restricted model

Model 2: $y(t)=A 0+A 1 g * P g+A 1 e^{*} P e 85+A 2 * \exp (A 3 * f)+A 4 * y(t-1)$, where $y(t)=L n(s e, t / s g, t)$

\begin{tabular}{ccccccc}
\hline & Res.Df & RSS & Df & Sum of Sq & F & $\operatorname{Pr}(>$ F $)$ \\
\hline 1 & 50 & 2.3997 & & & & \\
2 & 49 & 2.0257 & 1 & 0.37403 & 9.0476 & 0.004144 \\
\hline
\end{tabular}

Table 6b. Test for Equal and Opposite Sign of Price Coefficients for ND 2SLS Model

Linear hypothesis test

Hypothesis:

$\mathrm{A} 1 \mathrm{~g}+\mathrm{A} 1 \mathrm{e}=0$

Model 1: restricted model

Model 2: $y(t)=A 0+A 1 g * P g+A 1 e^{*} \operatorname{Pe} 85+A 2 * \exp (A 3 * f)+A 4 * y(t-1)$, where $y(t)=L n(s e, t / s g, t)$

\begin{tabular}{ccccccc}
\hline & Res.Df & RSS & Df & Sum of Sq & F & $\operatorname{Pr}(>$ F $)$ \\
\hline 1 & 50 & 2.3598 & & & & \\
2 & 49 & 2.0278 & 1 & 0.33196 & 8.0215 & 0.00669 \\
\hline
\end{tabular}


Table 7a. Test for Equal and Opposite Sign of Price Coefficients for IA NLS Model

Linear hypothesis test

Hypothesis:

$\mathrm{Alg}+\mathrm{Ale}=0$

Model 1: restricted model

Model 2: $y(t)=A 0+A 1 g * P g+A 1 e * P e 85+A 2 * \exp (A 3 * f)+A 4 * y(t-1)$, where $y(t)=L n(s e, t / s g, t)$

\begin{tabular}{ccccccc}
\hline & Res.Df & RSS & Df & Sum of Sq & F & $\operatorname{Pr}(>$ F $)$ \\
\hline 1 & 28 & 0.71438 & & & & \\
2 & 27 & 0.70211 & 1 & 0.012274 & 0.472 & 0.4979 \\
\hline
\end{tabular}

Table 7b. Test for Equal and Opposite Sign of Price Coefficients for IA 2SLS Model

Linear hypothesis test

Hypothesis:

$\mathrm{A} 1 \mathrm{~g}+\mathrm{A} 1 \mathrm{e}=0$

Model 1: restricted model

Model 2: $y(t)=A 0+A 1 g * P g+A 1 e^{*} P e 85+A 2 * \exp (A 3 * f)+A 4 * y(t-1)$, where $y(t)=L n(s e, t / s g, t)$

\begin{tabular}{ccccccc}
\hline & Res.Df & RSS & Df & Sum of Sq & F & $\operatorname{Pr}(>$ F $)$ \\
\hline 1 & 28 & 0.75682 & & & & \\
2 & 27 & 0.75190 & 1 & 0.0049213 & 0.1767 & 0.6775 \\
\hline
\end{tabular}

